This document was prepared in conjunction with work accomplished under Contract No. DE-AC09-96SR18500 with the U. S. Department of Energy.

\title{
DISCLAIMER
}

This report was prepared as an account of work sponsored by an agency of the United States Government. Neither the United States Government nor any agency thereof, nor any of their employees, nor any of their contractors, subcontractors or their employees, makes any warranty, express or implied, or assumes any legal liability or responsibility for the accuracy, completeness, or any third party's use or the results of such use of any information, apparatus, product, or process disclosed, or represents that its use would not infringe privately owned rights. Reference herein to any specific commercial product, process, or service by trade name, trademark, manufacturer, or otherwise, does not necessarily constitute or imply its endorsement, recommendation, or favoring by the United States Government or any agency thereof or its contractors or subcontractors. The views and opinions of authors expressed herein do not necessarily state or reflect those of the United States Government or any agency thereof. 
WSRC-TR-2005-00263, REV. 0

SRNL-RPP-2005-00039, REV. 0

\section{EVALUATION OF FOAMING AND ANTIFOAM EFFECTIVENESS DURING THE WTP OXIDATIVE LEACHING PROCESS}

SEPTEMBER 2005

\section{SAVANNAH RIVER NATIONAL LABORATORY}
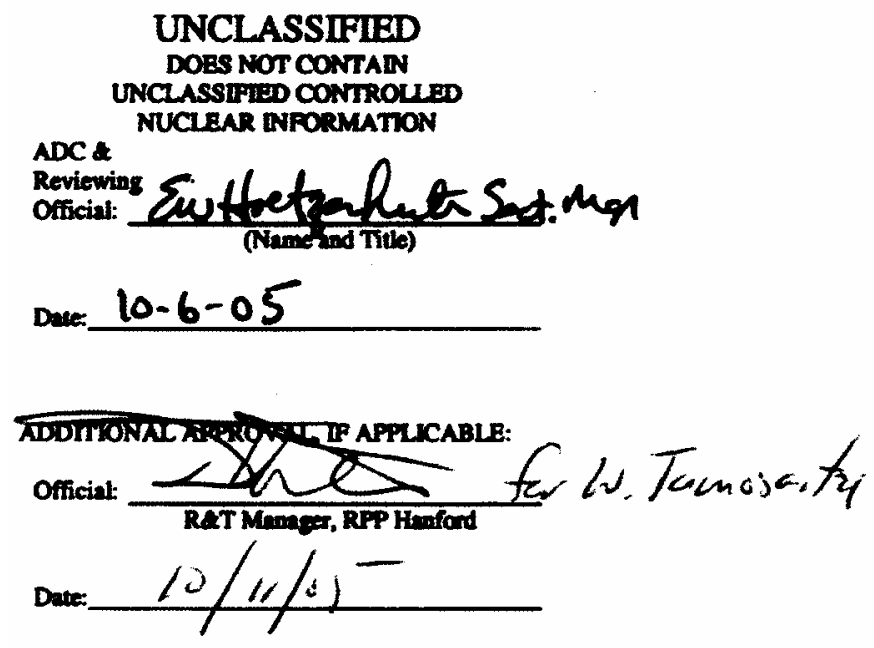

Westinghouse Savannah River Company Savannah River Site Aiken, SC 29808 
WSRC-TR-2005-00263, REV. 0

SRNL-RPP-2005-00039, REV. 0

\section{DISCLAIMER}

This report was prepared for the United States Department of Energy under Contract No. DE-AC09-96SR18500 and is an account of work performed under that contract. Neither the United States Department of Energy, nor WSRC, nor any of their employees makes any warranty, expressed or implied, or assumes any legal liability or responsibility for accuracy, completeness, or usefulness, of any information, apparatus, or product or process disclosed herein or represents that its use will not infringe privately owned rights. Reference herein to any specific commercial product, process, or service by trade name, trademark, name, manufacturer or otherwise does not necessarily constitute or imply endorsement, recommendation, or favoring of same by Westinghouse Savannah River Company or by the United States Government or any agency thereof. The views and opinions of the authors expressed herein do not necessarily state or reflect those of the United States Government or any agency thereof.

Printed in the United States of America

Prepared For

U.S. Department of Energy 
Key Words:

WTP Tanks Antifoaming

Oxidative Leaching

Retention:

Permanent

Key WTP R\&T References:

Test Specification:

24590-WTP-TSP-RT-05-0001, Rev. 0

Test Plan:

SRT-RPP-2005-00018

Test Exceptions:

NONE

R\&T Focus Area:

PRETREATMENT

\title{
EVALUATION OF FOAMING AND ANTIFOAM EFFECTIVENESS DURING THE WTP OXIDATIVE LEACHING PROCESS
}

\author{
P. R. Burket, SRNL \\ T. M. Jones, SRNL \\ T. L. White, SRNL \\ C. L. Crawford, SRNL \\ T. B. Calloway, SRNL
}

Issue Date: SEPTEMBER 2005

Westinghouse Savannah River Company

Savannah River Site

Aiken, SC 29808

Prepared for the U.S. Department of Energy Under Contract Number DE-AC09-96SR18500

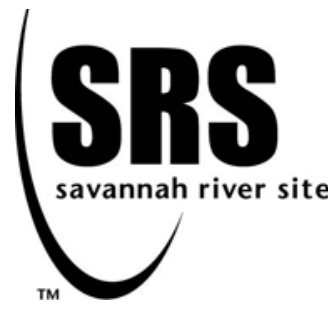


WSRC-TR-2005-00263, REV. 0 SRNL-RPP-2005-00039, REV. 0

\section{REVIEWS AND APPROVALS}

Panp Buatar

P. R. Burket, Author, ITS/SRNL

$\frac{7 \text { month tmes }}{\text { T. M. Jones, Co-author, ITS/SRNL }}$
$10 / 6105$

Date

Hamar Whito $10 / 6 / 05$

T. L White, Co-author, ADS/SRNL

Date

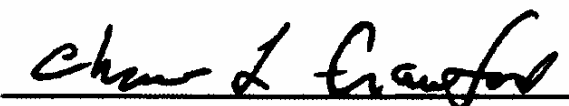

C. L. Crawford, Co-author, ITS/SRNL

$10 / 6 / 05$

Date

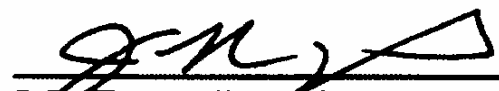

J. K. Zamecnik, TEchnical Reviewer

$\frac{10 / 6 / a 5}{\text { Date }}$
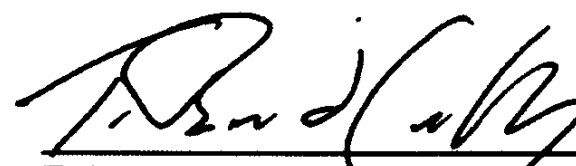

T. B. Calloway, Matager, Levd 4 Manager, RPP
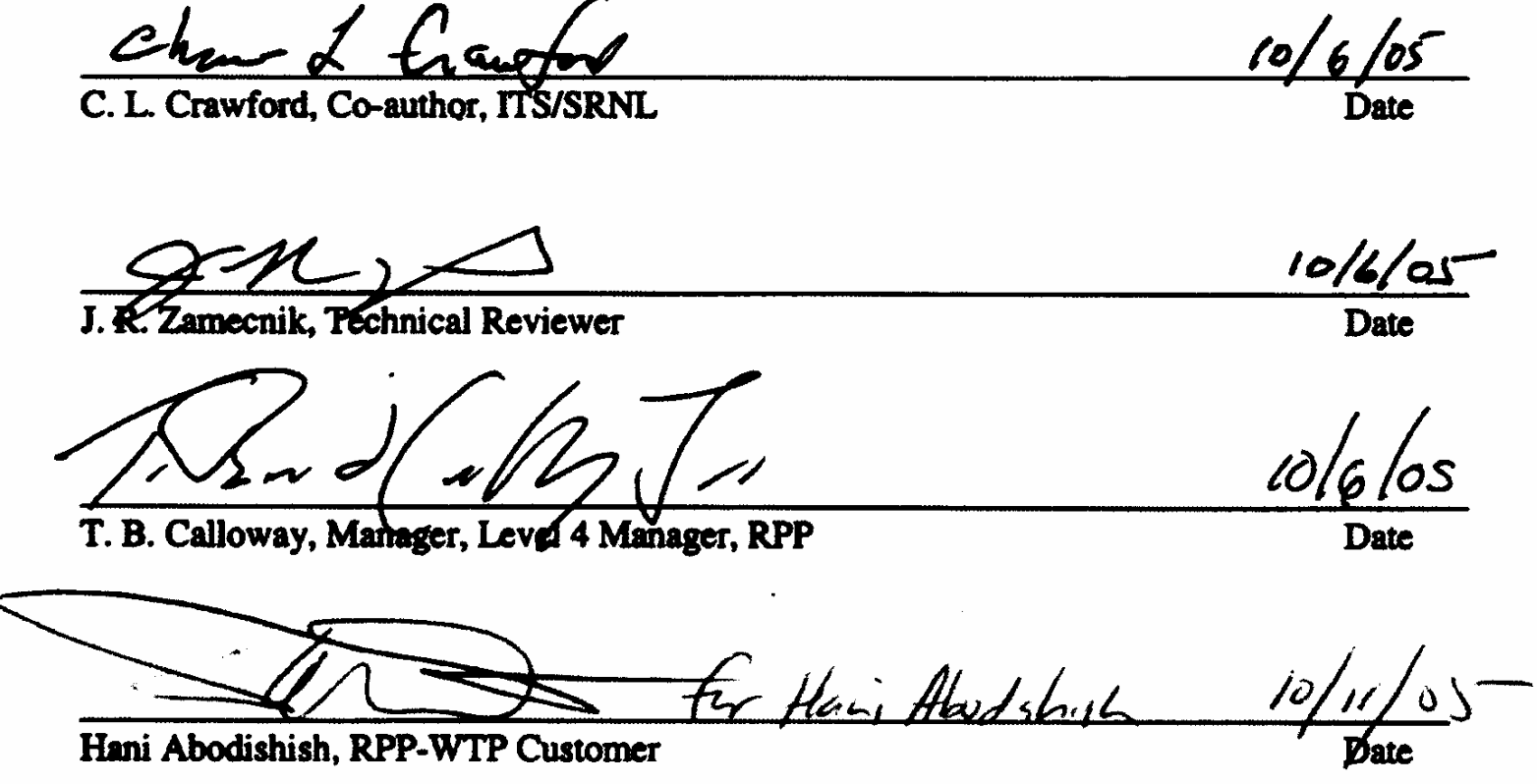
WSRC-TR-2005-00263, REV. 0 SRNL-RPP-2005-00039, REV. 0

\section{TABLE OF CONTENTS}

LIST OF FIGURES ...................................................................................................................... iv

LIST OF TABLES ........................................................................................................................... iv

LIST OF ACRONYMS ..................................................................................................... iv

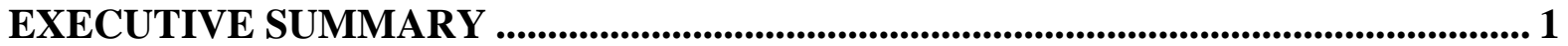

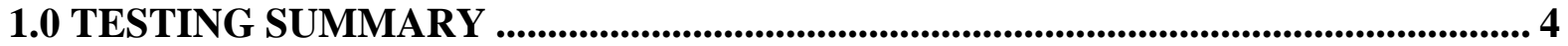

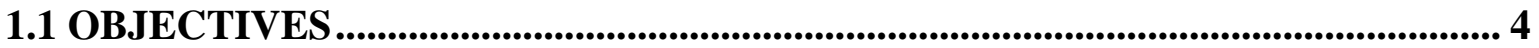

1.2 TEST EXCEPTIONS ........................................................................................................ 4

1.3 RESULTS AND PERFORMANCE AGAINST SUCCESS CRITERIA .................. 4

1.4 QUALITY REQUIREMENTS............................................................................ 4

1.5 R\&T TEST CONDITIONS ......................................................................................... 5

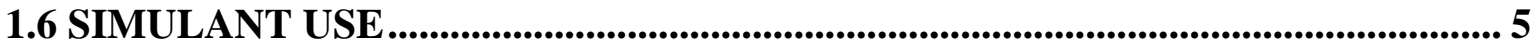

1.7 DISCREPANCIES AND FOLLOW-ON TESTS ........................................................... 5

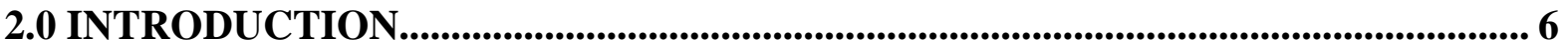

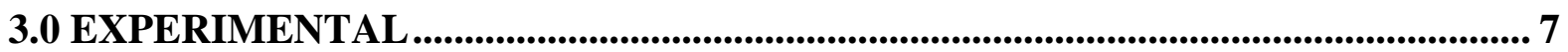

3.1 EXPERIMENTAL APPARATUS AND METHODOLOGY ...................................... 7

3.2 BASE SIMULANT FORMULATION ………............................................................. 11

3.3 SIMULANT FOAMING VS. Q2-3183A ANTIFOAM CONCENTRATION ....... 14

3.4 FOAMING VS. CAUSTIC LEACHING AND WASHING ..................................... 16

3.5 FOAMING VS. OXIDATIVE LEACHING \& WASHING VS. ppm Q2-3183A.. 16

3.6 FOAMING VS. WT\% UDS IN HIGH CHROME SLURRY ................................. 22

3.7 FOAMING VS. CAUSTIC LEACH \& OXIDATIVE LEACH AT BASELINE \& IDLE SPARGER FLUXES..................................................................................... 23

3.8 EFFECTIVENESS OF ANTIFOAMS Q2-3183A, Q2-3315, 1520US, AND IIT-747 DURING OXIDATIVE LEACHING ................................................................... 26

4.0 DISCUSSION / CONCLUSIONS................................................................................... 29

5.0 REFERENCES.................................................................................................................. 32

APPENDIX A. HIGH CHROMIUM ADDITION TO SIMULANT FOR OXIDATIVE

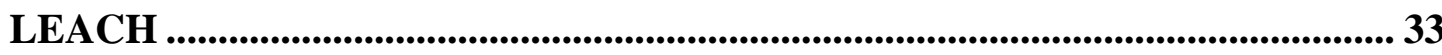

APPENDIX B. PERMANGANATE ADDITION TO SIMULANT FOR OXIDATIVE

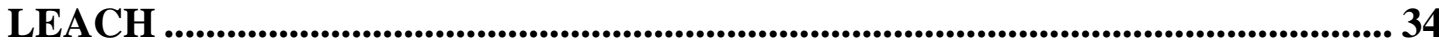

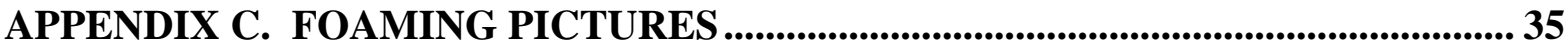




\section{LIST OF FIGURES}

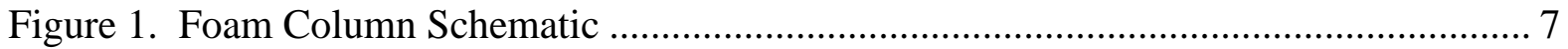

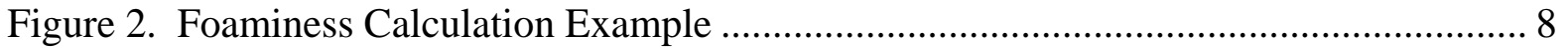

Figure 3. Caustic Leach Apparatus Schematic …………....................................................... 9

Figure 4. \%Foaminess vs. Permeate Dilution with Deionized Water........................................ 12

Figure 5. Foaminess vs. Wt\% UDS in 50/50 SIPP Wash 1 Permeate ...................................... 13

Figure 6. Foaminess of 12.9 wt\% UDS Slurry vs. Q2-3183A Concentration ........................ 15

Figure 7. Foaminess vs. Caustic Leach and Washing at Air Flux of $2.2 \mathrm{ft}^{3} / \mathrm{min} / \mathrm{ft}^{2} \ldots \ldots \ldots \ldots . . .16$

Figure 8. Oxidative Leaching and Washing of High Cr Slurry with No Antifoam............... 17

Figure 9. Oxidative Leaching and Washing of High Cr Slurry with Antifoam..................... 18

Figure 10. Oxidative Leaching and Washing of High Cr Slurry at Various Air Fluxes........ 19

Figure 11. Oxidative Leaching and Washing of Low Cr Slurry with No Antifoam .............. 20

Figure 12. Oxidative Leaching and Washing of Low Cr Slurry with 350 ppm Antifoam .... 21

Figure 13. Wt\% UDS vs Foaminess vs Q2-3183A................................................................ 22

Figure 14. Wt\% UDS vs Foaminess vs Q2-3183A, Zero Point Removed ............................. 22

Figure 15. Foaminess After Caustic Leach and Washes...................................................... 24

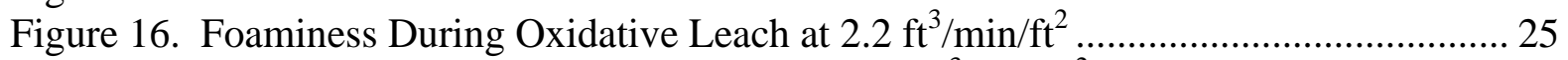

Figure 17. Foaminess During Oxidative Leach at $0.22 \mathrm{ft}^{3} / \mathrm{min} / \mathrm{ft}^{2}$..................................... 25

Figure 18. Difference in AY-102 Simulant Batches............................................................. 26

Figure 19. Foam Column with Recirculation Loop .............................................................. 27

Figure 20. Foaminess During Oxidative Leach for Various Antifoams at 0.22 Sparger Flux

Figure 21. Foaminess During Oxidative Leach for Various Antifoams at 2.2 Sparger Flux 28

\section{LIST OF TABLES}

Table 1. Wash Supernate Appearance After Oxidative Leach …………………................... 3

Table 2. Final Simulant Components.................................................................................. 14

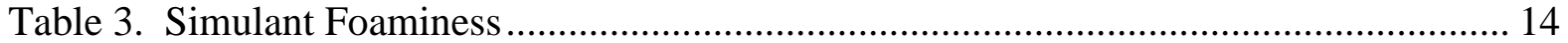

Table 4. Wash Supernate Appearance After Oxidative Leach .............................................. 30

\section{LIST OF ACRONYMS}

$\begin{array}{ll}\text { DOE } & \text { Department of Energy } \\ \text { HLW } & \text { High Level Waste } \\ \text { QA } & \text { Quality Assurance } \\ \text { PJM } & \text { Pulse Jet Mixers } \\ \text { RPP } & \text { River Protection Project } \\ \text { SIPP } & \text { Semi-Integrated Pilot Plant } \\ \text { SRNL } & \text { Savannah River National Laboratory } \\ \text { UDS } & \text { Undissolved Solids } \\ \text { WTP } & \text { Waste Treatment Plant }\end{array}$




\section{EXECUTIVE SUMMARY}

The River Protection Project-Waste Treatment Plant (RPP-WTP) requested Savannah River National Laboratory (SRNL) to conduct small-scale foaming and antifoam testing using a Hanford waste simulant subjected to air sparging during the oxidative leaching process ${ }^{1}$. The foaminess of Hanford tank waste solutions was previously demonstrated by SRNL during WTP evaporator foaming studies ${ }^{2}$ and commercial antifoam Dow Corning Q2-3183A was recommended to mitigate the foam in the evaporators and in WTP vessels equipped with pulse jets and air spargers ${ }^{3}$. Currently, WTP is planning to use air spargers in the HLW Lag Storage Vessels (HLP-VSL-00027A/B), the Ultrafiltration Vessels (UFP-VSL-00002A\&B), and the HLW Feed Blend Vessel (HLP-VSL-00028) to assist the performance of the Pulse Jet Mixers (PJM) ${ }^{1}$.

Objectives of this test are:

- Evaluate effectiveness of the recommended antifoam (Q2-3183A) under the oxidative leaching process.

- Develop an antifoam addition strategy for the oxidative leaching process if it is effective under certain conditions.

- Evaluate effectiveness of three other antifoams and compare performances to the baseline antifoam.

This report covers test 3 of the three antifoam tests per Test Specification 24590-WTP-TSP05-0001 to support WTP process design. Test \#1 focused on degradation products and rates for this antifoam and the test results are covered by WSRC report WRSC-TR-2004-00387 rev. 1. Test \#2 focused on the hydrogen generation rate from the baseline antifoam and the results are presented in WSRC report WRSC-TR-2005-00281.

The initial oxidative leaching tests were performed for the following conditions:

1. High ${ }^{\mathrm{a}}$ Insoluble Cr, No Antifoam

2. High Insoluble Cr, with Antifoam.

3. Low Insoluble Cr, No Antifoam

4. Low Insoluble Cr, with Antifoam

Oxidative leaching of $\mathrm{Cr}$ is accomplished with the addition of $1 \mathrm{M} \mathrm{NaMnO}_{4}$ at ambient temperature $\left(\sim 25^{\circ} \mathrm{C}\right)$. Tests 1 and 3 (no antifoam added, see Figures 8 and 11) both showed an increase in foaminess over slurry with no $\mathrm{NaMnO}_{4}$ added. Test 1 , high insoluble $\mathrm{Cr}$ simulant with no antifoam showed considerably more foaminess (>1000\% vs. a baseline simulant foaminess of 283\%) due to the $6 \mathrm{X}$ larger addition of $\mathrm{NaMnO}_{4}$. The maximum foam height occurred more than five hours after the addition of $\mathrm{NaMnO}_{4}$. Tests 2 and 4 (High and Low Insoluble $\mathrm{Cr}$, antifoam added, Figures 9 and 12) showed a rapid degradation in the effectiveness of the antifoam, possibly due to reaction with the $\mathrm{NaMnO}_{4}$ solution. The amount of foam produced by the oxidative leaching process is a strong function of the total $\mathrm{NaMnO}_{4}$ added to the vessel. While not completely understood at this time, the mechanism

${ }^{\mathrm{a}}$ Low $\mathrm{Cr}=3.17 \mathrm{mg} \mathrm{Cr} / \mathrm{g}$ washed solids and $\mathrm{High} \mathrm{Cr}=12 \mathrm{mg} \mathrm{Cr} / \mathrm{g}$ washed solids. 
causing the formation of foam during the oxidative leaching process is believed to be caused by insoluble Mn particles. A secondary cause for foaming in this process is believed to be caused by an unknown surfactant that is present in the base simulant.

The Q2-3183A antifoam was not very effective at reducing the foam during the oxidative leaching process at the baseline sparger air flux of $2.2 \mathrm{ft}^{3} / \mathrm{min} / \mathrm{ft}^{2}$. The antifoam reduced the foaminess to a maximum of $180 \%$ and $90 \%$ for the high and low insoluble Cr simulants, respectively. Previous SRNL foam column experiments, that were conducted to simulate air sparge tank systems, showed that an initial charge of $345 \mathrm{ppm}$ antifoam reduced the foaminess of a Hanford tank waste sample AN-104, with $9 \mathrm{wt} \%$ undissolved solids, to 13\% foam $^{3}$. Therefore, Q2-3183A is not recommended for use during the oxidative leaching process at the baseline sparger air flow of $2.2 \mathrm{ft}^{3} / \mathrm{min} / \mathrm{ft}^{2}$. Based on the results of this test, WSRC recommends WTP engineering to evaluate alternative mixing strategy, such as recirculation pumping, during the oxidative leaching process. This will mitigate the need of adding excessive antifoam during normal leaching operation.

Further testing was performed with Q2-3183A as well as three other antifoams at the idle sparger air flux of $0.22 \mathrm{ft}^{3} / \mathrm{min} / \mathrm{ft}^{2}$ during the oxidative leaching process. As discussed in section 4.7 of this report, the performance of the antifoam Q2-3183A was satisfactory during the oxidative leaching process when the sparger air flux was controlled to $0.22 \mathrm{ft}^{3} / \mathbf{m i n} / \mathrm{ft}^{2}$. With no additional Q2-3183A added just prior to the oxidative leach, the foaminess remained under 7\%. By adding 350 ppm Q2-3183A just prior to oxidative leaching, the foaminess remained under $2 \%$.

By running with the sparger flux at the baseline flux of $2.2 \mathrm{ft}^{3} / \mathrm{min} / \mathrm{ft}^{2}$, the foaminess rose to $57 \%$ and $44 \%$ during oxidative leaching for the cases of no additional Q2-3183A added just prior to the oxidative leach and 350 ppm Q2-3183A added just prior to oxidative leaching. Note that these foaminess values are lowered by the addition of $350 \mathrm{ppm}$ Q2-3183A to the slurry just prior to an initial caustic leach and washing procedure that was performed on the slurry prior to the oxidative leach. This test further documents that mixing should not be performed with the sparger during the oxidative leaching process.

Additional bench scale studies were also performed to test other antifoams for the oxidative leaching process. Section 4.8 of this report investigated the use of Dow Corning Q2-3315, DeBourg 747, and Dow Corning 1520US antifoams during the oxidative leaching process. In all cases, the Q2-3183A antifoam outperformed the other antifoams tested.

Washing of the oxidative leached slurry was performed with six successive dilutions of $2.7 \mathrm{ml} 0.01 \mathrm{M} \mathrm{NaOH}$ to $30 \mathrm{ml}$ of slurry. Between dilutions, the wash and slurry was centrifuged, and an equivalent amount of supernate was drawn off. The appearance of the supernate from the washes provides some clues to the oxidative leaching process as illustrated in Table 1. 
WSRC-TR-2005-00263, REV. 0

SRNL-RPP-2005-00039, REV. 0

Table 1. Wash Supernate Appearance After Oxidative Leach

\begin{tabular}{|l|l|}
\hline Test & Supernate Appearance \\
\hline High Cr, No Antifoam & Clear purple, then green, then yellow \\
\hline High Cr, with Antifoam & Cloudy yellow \\
\hline Low Cr, No Antifoam & Clear yellow \\
\hline Low Cr, with Antifoam & Clear yellow \\
\hline
\end{tabular}

For the high $\mathrm{Cr}$, no antifoam case, the purple color of the supernate indicates that there was still some reactive $\mathrm{NaMnO}_{4}$ left over after the leaching process. This $\mathrm{NaMnO}_{4}$ could damage the ion exchange columns downstream in the WTP process. One possible reason for the remaining $\mathrm{NaMnO}_{4}$ is mixing of the slurry only occurred for about 5 minutes per hour for the first seven hours of the leach process and then 5 more minutes at the end of the process.

For the high $\mathrm{Cr}$, with antifoam case, the cloudiness of the supernate is an indication of the antifoam degradation due to reaction with the $\mathrm{NaMnO}_{4}$. The low $\mathrm{Cr}$, with antifoam runs did not create a cloudy wash permeate. Two reasons why the high $\mathrm{Cr}$ runs may have had more antifoam degradation whereas the low Cr runs did not are: 1) the high Cr runs had a $6 \mathrm{X}$ greater concentration of $\mathrm{NaMnO}_{4}$ than the low Cr runs, 2) the high Cr runs used $2 \mathrm{X}$ and $4 \mathrm{X}$ the amount of antifoam as the low Cr runs used.

Washing of the low Cr, with antifoam runs caused an increase in the slurry foaminess which is probably due to the dilution and removal of the antifoam from the slurry during washing. Washing of the runs which had no antifoam caused a decrease in slurry foaminess which is probably due to the reduction of dissolved solids.

Recommendations from this study are:

- The Dow Q2-3183A antifoam is not effective during the oxidative leaching process at the existing sparging flow and is not recommended for use in this condition. WSRC would recommend WTP to consider alternate mixing strategy, such as recirculation pumping, during the oxidative leaching operation.

- The Dow Q2-3183A antifoam is effective at idle sparging flow and should be used to control foaming post Design Basis Event condition. 350 ppm of Q2-3183A antifoam is recommended to use to reduce foaming as long as the spargers are controlled at idle flow.

- $\quad$ Based on the four antifoams tested, Dow Q2-3183A out performs other antifoams and is recommended for WTP use.

- Based on the results of these tests, no additional antifoam test work is recommended. However, preliminary data generated by SRNL in support of the Office of Science indicated that slurries generated in the Sr/TRU precipitation process also foam. WTP may consider performing tests to minimize foaming during the precipitation operation. 
WSRC-TR-2005-00263, REV. 0

SRNL-RPP-2005-00039, REV. 0

\subsection{TESTING SUMMARY}

\subsection{OBJECTIVES}

\begin{tabular}{|l|l|l|}
\hline Test Objective & $\begin{array}{l}\text { Objective } \\
\text { Met (Y/N) }\end{array}$ & Discussion \\
\hline $\begin{array}{l}\text { 1.Evaluate degradation of } \\
\text { antifoam effectiveness during } \\
\text { oxidative leaching }\end{array}$ & Y & $\begin{array}{l}\text { The foaminess of the Hanford } \\
\text { simulant was determined without } \\
\text { oxidative leaching, with oxidative } \\
\text { leaching at 3.17 mg Cr/g slurry, and } \\
\text { with oxidative leaching at 12 mg } \\
\text { Cr/g slurry. See section 3.3. }\end{array}$ \\
\hline $\begin{array}{l}\text { 2. Develop an addition strategy } \\
\text { for the oxidative leaching } \\
\text { process. }\end{array}$ & Y & $\begin{array}{l}\text { 350 ppm of Q2-3183A antifoam } \\
\text { was effective at reducing the foam } \\
\text { in the oxidative leaching process as } \\
\text { long as the sparger air flux was } \\
\text { controlled to 0.22 } \mathrm{ft}^{3} / \mathrm{min} / \mathrm{ft}^{2} \text {. }\end{array}$ \\
\hline $\begin{array}{l}\text { 3. Test three alternate antifoams } \\
\text { during the oxidative leaching } \\
\text { process. }\end{array}$ & Y & $\begin{array}{l}\text { The Q2-3183A out performs the } \\
\text { other three antifoams tested. }\end{array}$ \\
\hline
\end{tabular}

\subsection{TEST EXCEPTIONS}

\begin{tabular}{|l|l|}
\hline List Test Exceptions & Describe Test Exceptions \\
\hline 1. None & \\
\hline
\end{tabular}

\subsection{RESULTS AND PERFORMANCE AGAINST SUCCESS CRITERIA}

\begin{tabular}{|l|l|}
\hline List Success Criteria & $\begin{array}{l}\text { Explain How the Tests Did or Did Not } \\
\text { Meet the Success Criteria }\end{array}$ \\
\hline $\begin{array}{l}\text { 1. Accurate assessment and evaluation of } \\
\text { effectiveness of the antifoam during } \\
\text { oxidative leaching operations. }\end{array}$ & $\begin{array}{l}\text { Test results met success criteria by } \\
\text { measuring foam height with and without } \\
\text { antifoam. See sections 4.5 and 4.6. }\end{array}$ \\
\hline
\end{tabular}

\subsection{QUALITY REQUIREMENTS}

This work was requested by Hanford per test specification 24590-WTP-TSP-05-0001 ${ }^{1}$. The technical task plan, WSRC-TR-2005-0012 ${ }^{4}$, provides the matrices to WTP demonstrating compliance of the SRNL QA program with the requirements specified by WTP. 
This work was conducted in accordance with the RPP-WTP QA requirements specified for work conducted by SRNL as identified in DOE IWO M0SRLE60. SRNL has provided matrices to WTP demonstrating compliance of the SRNL QA program with the requirements specified by WTP. Specific information regarding the compliance of the SRNL QA program with RW-0333P, Revision 10, NQA-1 1989, Part 1, Basic and Supplementary Requirements and NQA-2a 1990, Subpart 2.7 is contained in these matrices.

\subsection{R\&T TEST CONDITIONS}

\begin{tabular}{|l|l|}
\hline List R\&T Test Conditions & Were Test Conditions Followed? \\
\hline $\begin{array}{l}\text { 1. Study of Make up Slurry with no } \\
\text { Treatment }\end{array}$ & YES. See section 4.3. \\
\hline $\begin{array}{l}\text { 2. Study with Minimum Cr Treatment } \\
\text { without Antifoam }\end{array}$ & YES. See section 3.5. \\
\hline $\begin{array}{l}\text { 3. Study with Minimum Cr Treatment with } \\
\text { Antifoam }\end{array}$ & YES. See section 3.5. \\
\hline $\begin{array}{l}\text { 4. Study with Maximum Cr Treatment } \\
\text { without Antifoam }\end{array}$ & YES. See section 3.5. \\
\hline $\begin{array}{l}\text { 5. Study with Maximum Cr Treatment } \\
\text { with Antifoam }\end{array}$ & YES. See section 3.5. \\
\hline $\begin{array}{l}\text { 6. Study with varying solids levels with } \\
\text { Antifoam }\end{array}$ & YES. See section 4.6. \\
\hline $\begin{array}{l}\text { 7. Perform oxidative leach per WTP-RPT- } \\
\text { 117 Rev.0 (DRAFT) }\end{array}$ & $\begin{array}{l}\text { YES. The procedure was followed with } \\
\text { some minor exceptions. See section 4.1. }\end{array}$ \\
\hline $\begin{array}{l}\text { 8. Perform oxidative leach of high Cr } \\
\text { Slurry with sparger flux at idle }\end{array}$ & YES. See section 4.7. \\
\hline $\begin{array}{l}\text { 9. Test alternate antifoams at both idle and } \\
\text { baseline sparger fluxes during the oxidative } \\
\text { leaching process. }\end{array}$ & YES. See section 4.8. \\
\hline
\end{tabular}

\subsection{SIMULANT USE}

The Semi-Integrated Pilot Plant (SIPP) AY102/C106 simulant created during the SIPP filtration of this simulant was used for these experiments ${ }^{5}$. This simulant was diluted with SIPP filter caustic wash solutions and deionized water to increase foaminess of the slurry. In previous testing by Hassan et al. ${ }^{3}$, slurries were diluted to study the effect of insoluble solids concentrations on foaming.

Refer to section 3.2 for a description of the simulant formulation.

\subsection{DISCREPANCIES AND FOLLOW-ON TESTS}

None 


\subsection{INTRODUCTION}

The River Protection Project-Waste Treatment Plant (RPP-WTP) requested Savannah River National Laboratory (SRNL) to conduct small-scale foaming and antifoam testing using a Hanford waste simulant subjected to air sparging during oxidative leaching ${ }^{1}$. The foaminess of Hanford tank waste solutions was previously demonstrated by SRNL during WTP evaporator foaming studies and in small scale air sparger studies ${ }^{2,3}$. The commercial antifoam, Dow Corning Q2-3183A was recommended to mitigate the foam in the evaporators and in vessel equipped with pulse jet mixers and air spargers. Currently, WTP is planning to use air spargers in the HLW Lag Storage Vessels (HLP-VSL-00027A/B), the Ultrafiltration Vessels (UFP-VSL-00002A\&B), and the HLW Feed Blend Vessel (HLPVSL-00028) to assist the performance of the Pulse Jet Mixers (PJM). The previous air sparger antifoam studies conducted by SRNL researchers ${ }^{3}$ did not evaluate the hydrogen generation rate expected from antifoam additions or the effectiveness of the antifoam during caustic leaching or oxidative leaching. The fate of the various antifoam components and breakdown products in the WTP process under prototypic process conditions (temperature \& radiation) was also not investigated. The effectiveness of the antifoam during caustic leaching, expected hydrogen generation rate associated with antifoam addition, and the fate of various antifoam components are being conducted under separate SRNL research tasks ${ }^{4,6}$. 
WSRC-TR-2005-00263, REV. 0

SRNL-RPP-2005-00039, REV. 0

\subsection{EXPERIMENTAL}

\subsection{EXPERIMENTAL APPARATUS AND METHODOLOGY}

The apparatus used to perform the foaming tests is the exact same apparatus used and described in "Evaluation of Foaming/Antifoaming In WTP Tanks Equipped With Pulse Jet Mixers And Air Spargers,” WSRC-TR-2004-00387³. Many details regarding bubble size, wall effects, etc. are described in that report which will not be discussed in this report.

The apparatus used to perform the foaming and antifoam experiments consisted of a glass column (3.1 cm diameter x $60 \mathrm{~cm}$ height) with graduations along the column wall, an air flow metering device with a three-way valve, a Disto ${ }^{\mathrm{TM}}$ Pro4 laser measuring device, and a Sony ${ }^{\mathrm{TM}}$ Mini-DV video recording camera. The foam column had a coarse fritted disk with 75-100 micron holes fitted into its base. The small bubbles created by the fritted disk were used to simulate a larger air sparger bubble broken up by introduction into a recirculation pump or sheared by some other means.

To provide the air sparging, air was introduced into the column through a $0.6 \mathrm{~cm}$ (1/4-inch) i.d. tube directly below the fritted disk. The flow of air was controlled by a mass flow meter (MKS Instruments, Inc.) to attain air flow rates of $0.25,0.5,0.75$, and $1.0 \mathrm{~L} / \mathrm{min}$. These flows correspond to air fluxes of $1.1,2.2,3.3,4.4 \mathrm{ft}^{3} / \mathrm{min} / \mathrm{ft}^{2}$. A three-way valve below the column air-supply tube was utilized to divert air away from the column during intermittent air flux changes between tests. Figure 1 shows a schematic of the foam column.

Figure 1. Foam Column Schematic

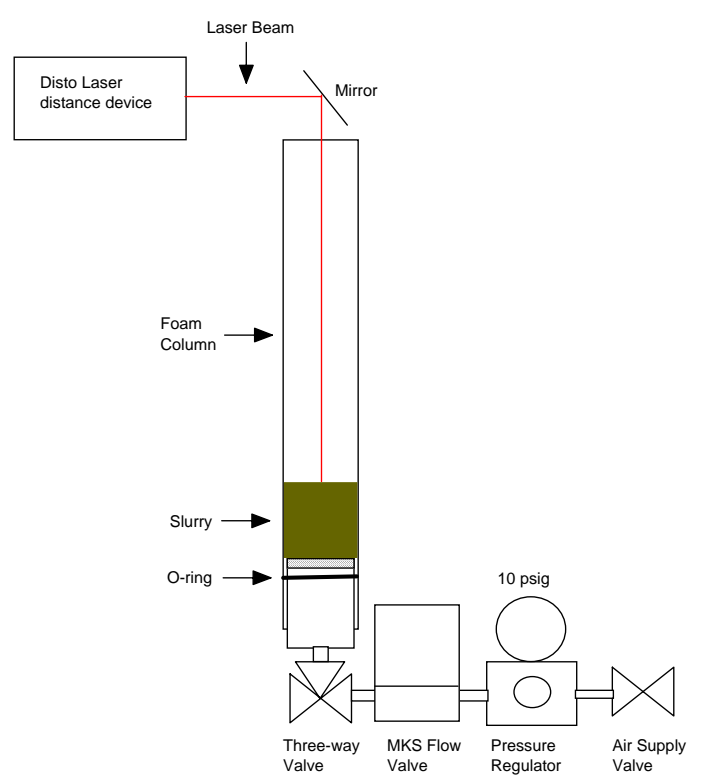


The foam height was measured by using a Disto Pro4 ${ }^{\mathrm{TM}}$ laser height detector or by visual inspection versus a centimeter/millimeter scale along the glass wall of the foaming column.

The percent foaminess was calculated per the following equations which were used and described in "Evaluation of Foaming/Antifoaming In WTP Tanks Equipped With Pulse Jet Mixers And Air Spargers”, WSRC-TR-2004-00387².

H1 = height of liquid at rest

H2 = height of liquid at known air flux

Degree of air incorporated $=(\mathrm{H} 2-\mathrm{H} 1) / \mathrm{H} 1$

Gas holdup $=(\mathrm{H} 2-\mathrm{H} 1) / \mathrm{H} 2^{\mathrm{b}}$

$\%$ Foaminess $=100 \times$ (Degree of air incorporated - gas holdup $)$

Figure 2 shows an example of this calculation.

Figure 2. Foaminess Calculation Example
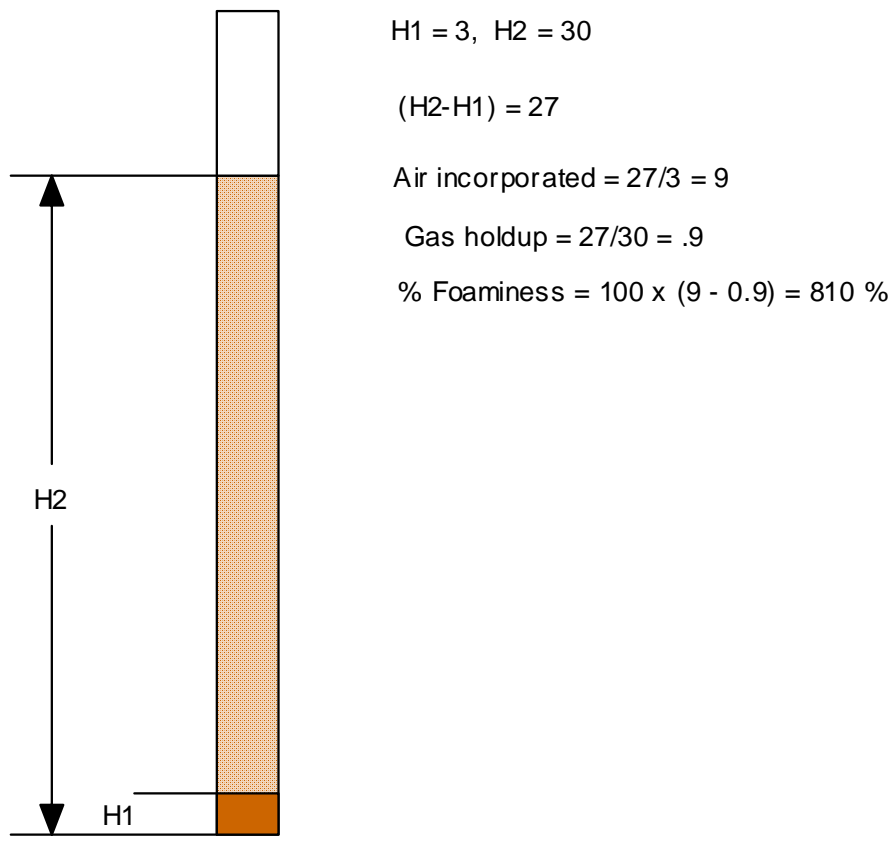

b Euzen, J. P., P. Trambouzer \& J. P. Wauguier, “Scale-up Methodology for Chemical Processes”, Gulf Publishing Co., New York, p. 130(1993) 
Caustic leaching was performed in a $250 \mathrm{ml}$ Pyrex beaker, covered with aluminum foil, which was partially submerged in a water bath which was heated by a hot plate so that the temperature of the slurry in the $250 \mathrm{ml}$ beaker was $85^{\circ} \mathrm{C}$. A separate heater kept standby bath water at $85^{\circ} \mathrm{C}$ for addition to the caustic leach bath (due to evaporative losses) to avoid a temperature disturbance. Figure 3 shows a schematic of the caustic leach apparatus.

Figure 3. Caustic Leach Apparatus Schematic

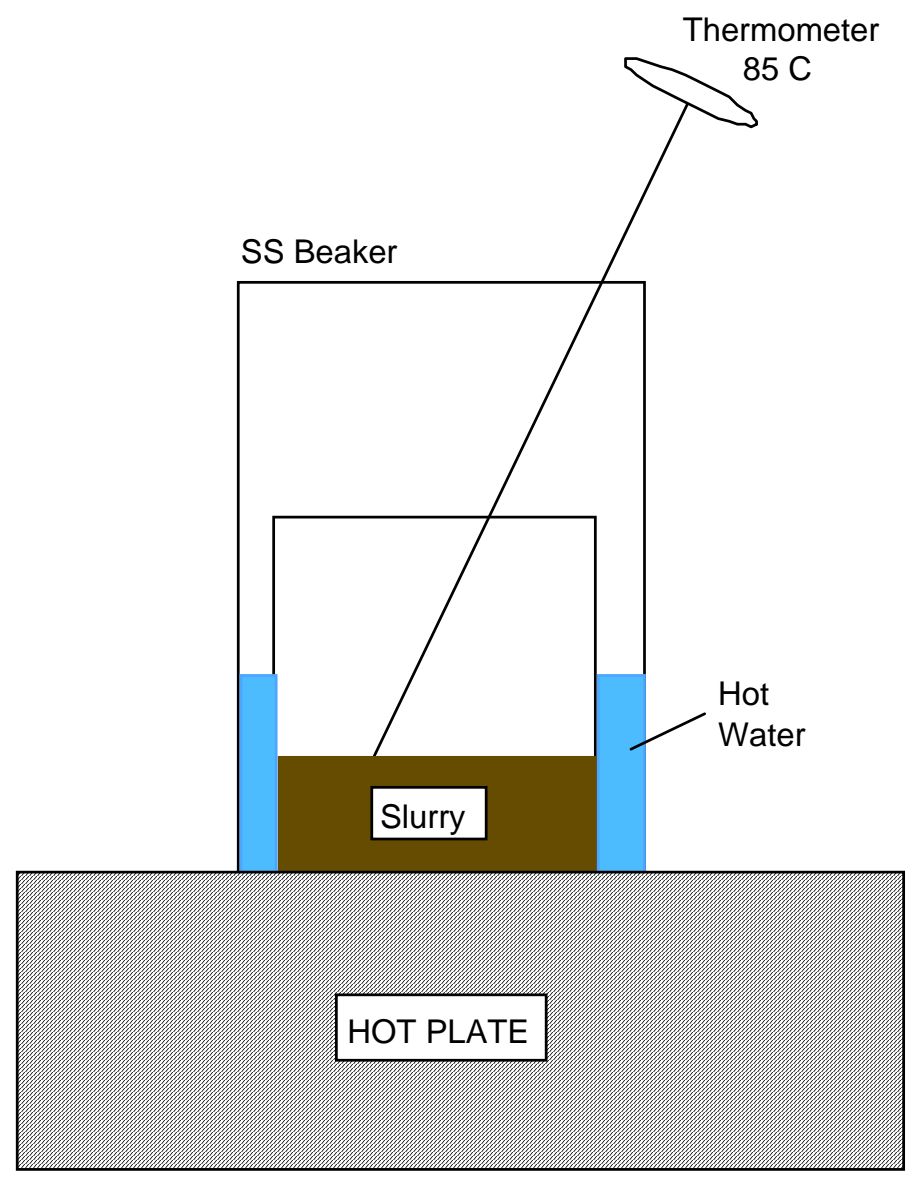

Fifty ml of slurry was treated with $19 \mathrm{M}$ caustic to attain a $3 \mathrm{M}$ caustic solution per 24590PTF-3YD-UFP-00001, Rev. A, page $13^{7}$. The solution was mixed, and then heated to 80 $90{ }^{\circ} \mathrm{C}$ for 8 hours. The solution was allowed to cool overnight. Washing was performed per the modified wash procedure of WSRC-TR-2003-00240 rev 0, page $10^{8}$. Six washes were performed using $4.5 \mathrm{ml}$ inhibited water per $50 \mathrm{ml}$ of leached slurry.

Oxidative leaching occurred in the foam column shown in Figure 1. One molar $\mathrm{NaMnO}_{4}$ solution or $10000 \mathrm{ppm}$ Q2-3183A antifoam solution were added to the column via a calibrated auto-pipette. The pipettes were calibrated prior to each use using a calibrated scale and de-ionized water. 
With WTP Engineering concurrance approval, the lower and upper Cr levels to be leached from the washed slurry were $3.17 \mathrm{mg} \mathrm{Cr} / \mathrm{g}$ UDS and $12 \mathrm{mg} \mathrm{Cr} / \mathrm{g}$ UDS in the slurry respectively. The chromium in the base slurry was determined and additional chromium was added in the form of $\mathrm{Cr}_{2} \mathrm{O}_{3}$, a green non-water-soluble solid, to simulate higher chromium slurries for oxidative leaching. The calculations for the amount added for the high $\mathrm{Cr}$ concentration are shown in Appendix A. The calculations for the amount of $1 \mathrm{M} \mathrm{NaMnO}_{4}$ solution required for the high Cr content slurry are shown in Appendix B.

The oxidative leaching procedure as referenced from WTP-RPT-117 Rev. 0 is shown in the numbered instructions below.

1. Caustic leach as currently designed.

2. Cool to $25{ }^{\circ} \mathrm{C}$.

3. Re-concentrate to original batch volume.

4. Wash as currently designed.

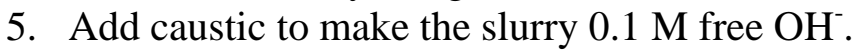

6. Add $1 \mathrm{M} \mathrm{NaMnO}$ at 1.1:1 ratio with $\mathrm{Cr}$ in unwashed solids.

7. Allow 16 hours for reaction.

8. Concentrate solids to $20 \mathrm{wt} \%$.

9. Wash solids as currently designed.

Minor exceptions to this procedure are:

Step 1: Caustic leach was not performed in order to preserve the foaminess of simulant prior to the oxidative leach.

Step 3: Used $12.9 \mathrm{wt} \%$ UDS slurry for greatest initial foaminess.

Step 4: Not applicable since there was no caustic leach and the slurry was made up with wash solutions and undissolved AY102 slurry. The slurry was therefore partially washed to a $\mathrm{pH}$ of 13.6.

Step 5: The slurry had a measured $\mathrm{pH}$ of 13.6 so no caustic was added since the free $\mathrm{OH}$ was assumed to be greater than $0.1 \mathrm{M} \mathrm{OH}^{-}(\mathrm{pH}=13)$.

Step 7: Final slurry foaminess testing didn’t occur until about 22 hours after addition of $\mathrm{NaMnO}_{4}$ solution.

Step 9: Performed using a modified six step wash procedure as described in steps 916 below. Note that sample size for all leaches was $30 \mathrm{ml}$.

Performance of an oxidative leach and wash was as follows:

1. Transfer 50 grams of $12.9 \mathrm{wt} \% \mathrm{AY}-102 / \mathrm{C}-106$ slurry into a beaker.

2. Add appropriate amount of $\mathrm{Cr}_{2} \mathrm{O}_{3}$ and mix well.

3. Transfer 35.4 grams of slurry into the foam column.

4. Add antifoam (if called for).

5. Turn ON air sparge at $0.50 \mathrm{~L} / \mathrm{min}$ for 1 minute to mix antifoam into slurry.

6. Add appropriate amount of $\mathrm{NaMnO}_{4}$ solution. 
7. Start clock and perform foaming tests at least once per hour until quitting time.

8. Perform foaming test at start of work on next day.

WASHING

9. Pour slurry from foam column into $50 \mathrm{ml}$ centrifuge tube.

10. Add $2.7 \mathrm{ml}$ of $0.01 \mathrm{M} \mathrm{NaOH}$ solution. (NOTE: no antifoam agent was in the wash solutions)

11. Shake well.

12. Centrifuge at setting 4 for 10 minutes.

13. Remove $2.7 \mathrm{ml}$ of supernate with a slurry pipette. Put supernate into a sample bottle.

14. Shake well and visually insure homogeneous slurry is obtained.

15. Pour slurry back into foam column after wash 1 , wash 3 , and wash 6 for foam test.

16. After wash 6 foam test, pour slurry into sample bottle for storage.

\subsection{BASE SIMULANT FORMULATION}

The objective of this experiment was to study changes in simulant foaminess and antifoam effectiveness due to the oxidative leaching process. Therefore, a simulant based upon the composition of Hanford tank AY102/C106 was formulated since this simulant was shown to foam previously by Hassan ${ }^{3}$. This simulant was derived from solutions created during the processing simulant AY-102/C-106 through the Semi-Integrated Pilot Plant (SIPP). Wash solutions ("Wash 1 Permeate and Wash 2 Permeate") created during the washing of AY102/C106 were combined with AY102/C106 undissolved solids to form the simulant. Wash 1 Permeate was created during the first cycle (22 washes) of washing the AY102/C106 simulant. Wash 2 Permeate was created during the second cycle (22 washes) of washing the AY102/C106 simulant. AY102/C106 simulant foams primarily due to the presence of an unknown surfactant. The undissolved solids present in AY102/C106 simulant also help stabilize the foam to some degree. Thus, for the purposes of this testing, the AY102/C106 simulant formulated provides a reasonable model of Hanford tank waste AN104 (contains foaming surfactant \& AY102/C106 solids simulant tested previously by Hassan et. al.)

SIPP wash solutions were further modified by diluting with water. Tests used the "Wash 1 Permeate" from the Hanford waste simulant AY-102/C-106 (campaign IV of the SIPP operation) $)^{5}$. Figure 4 shows the results of diluting the SIPP Wash 1 Permeate with deionized water. 
Figure 4. \%Foaminess vs. Permeate Dilution with Deionized Water

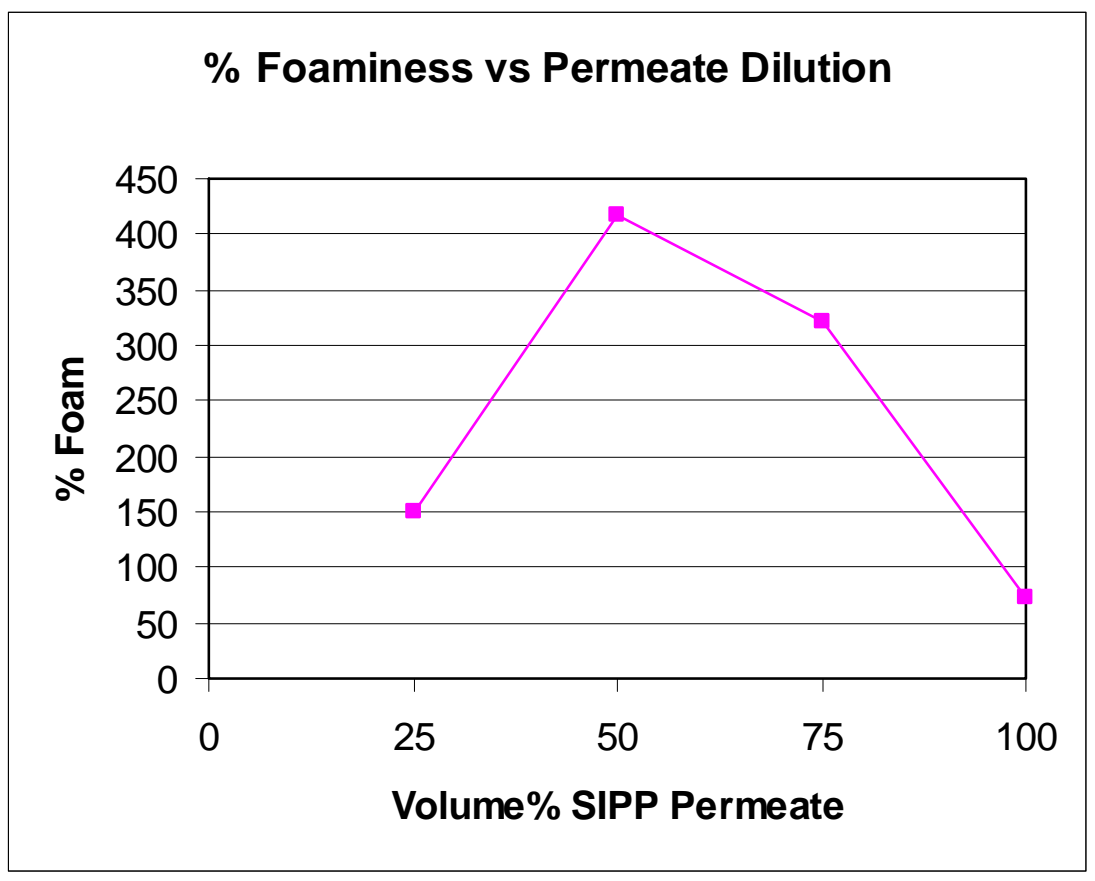

Figure 4 shows that the dilution of the permeate has a great effect on foaminess and that the peak foaminess is at or near the $50 \%$ dilution point of the wash 1 permeate. Diluting the electrolyte concentration in aqueous solutions containing surfactants is known to increase the effectiveness ( $\&$ in this case the foaminess) of the surfactant. Increasing salt concentration inhibits ordering of the surfactant micelles because the added ions compress the electric double layer surrounding the micelles resulting in a dramatic decrease in the effective volume (\& effectiveness) of the surfactant micelles ${ }^{9}$. Since the Wash 1 Permeate contained $20.78 \mathrm{wt} \%$ dissolved solids, a dissolved solids content near $11 \mathrm{wt} \%$ represents the worst case foaminess for this solution.

A second parameter that affects foaminess is the wt\% undissolved solids (UDS). The starting material for the solids is the $20 \mathrm{wt} \%$ UDS slurry product from campaign IV product of the SIPP operation ${ }^{5}$. These solids were diluted to 15.3, 12.9, and $8.4 \mathrm{wt} \%$ UDS with Wash 1 Permeate that was diluted by $50 \%$ with de-ionized water. Therefore, this simulant represents AY102/C106 slurries that are expected to be encountered during the washing of AY102/C106 Hanford tank waste. Figure 5 shows the results of this experiment. 
WSRC-TR-2005-00263, REV. 0

SRNL-RPP-2005-00039, REV. 0

Figure 5. Foaminess vs. Wt\% UDS in 50/50 SIPP Wash 1 Permeate

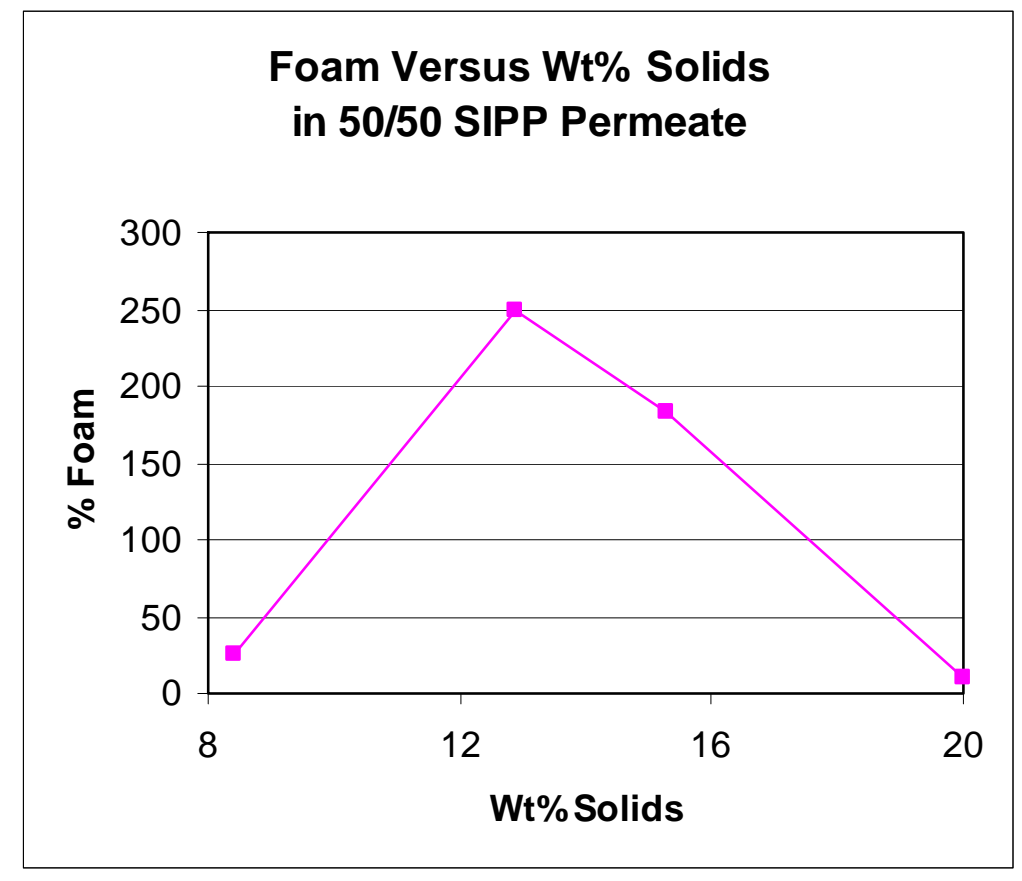

Figure 5 shows that the wt\% UDS of the slurry has a great effect on foaminess and that the peak foaminess is at or near $12.9 \mathrm{wt} \%$ UDS slurry.

Thus, for these experiments a single batch of $12.9 \mathrm{wt} \%$ UDS AY102/C106 slurry was made by mixing 50/50 diluted Wash 1 Permeate with 20 wt\% UDS AY102/C106 slurry. Analysis of the experiments and simulant volume required determined that about 1 liter of simulant was required. However, there was only enough of the wash 1 permeate to make-up $500 \mathrm{ml}$ of $12.9 \mathrm{wt} \%$ UDS slurry.

Thus in an effort to find more wash 1 permeate, only wash 2 permeate could be obtained. A foaming test of the SIPP Wash 2 Permeate showed 594\% foaminess at $2.2 \mathrm{ft}^{3} / \mathrm{min} / \mathrm{ft}^{2}$ compared to $417 \%$ for the 50/50 Wash 1 Permeate at the same flux. Wash 2 Permeate was generated during the second cycle of washing AY102/C106 in the SIPP. Wash 2 Permeate foams more than Wash 1 Permeate because the electrolyte concentration is higher in the Wash 1 Permeate. The dissolved solids of the wash 2 permeate was $8.96 \%{ }^{5}$ which is close to the $11 \mathrm{wt} \%$ obtained by diluting the wash 1 permeate by $50 \%$.

The simulant was actually made as two batches. The first batch was $500 \mathrm{ml}$ made from 50/50 wash 1 permeate plus water mixed with $20 \mathrm{wt} \%$ UDS slurry. The second batch was $650 \mathrm{ml}$ made from wash 2 permeate mixed with $20 \mathrm{wt} \%$ UDS slurry. The final slurry was the mixture of the two batches together.

The final simulant components are as follows in Table 2. 
WSRC-TR-2005-00263, REV. 0

SRNL-RPP-2005-00039, REV. 0

Table 2. Final Simulant Components

\begin{tabular}{|l|l|}
\hline Component & Milliliters \\
\hline DI Water & 93.75 \\
\hline Wash 1 permeate of SIPP Campaign IV & 93.75 \\
\hline Wash 2 permeate of SIPP Campaign IV & 243.75 \\
\hline 20 wt\% UDS SIPP Campaign IV product & 719 \\
\hline
\end{tabular}

The foaminess of each batch and of the combined batches is shown in Table 3 .

Table 3. Simulant Foaminess

\begin{tabular}{|l|l|l|}
\hline Permeate Type & Volume 12.9 wt\% Slurry & Foaminess at 2.2 Flux \\
\hline $50 / 50$ Wash 1 & $500 \mathrm{ml}$ & $293 \%$ \\
\hline Wash 2 & $650 \mathrm{ml}$ & $265 \%$ \\
\hline Combined Slurries Above & $1150 \mathrm{ml}$ & $283 \%$ \\
\hline
\end{tabular}

The final simulant with a foaminess of $283 \%$ at the design basis plant air flux was used for these tests.

The specific gravity of the $12.9 \mathrm{wt} \%$ UDS simulant was $1.18 \mathrm{~g} / \mathrm{ml}$. All foam column tests using the $12.9 \mathrm{wt} \%$ slurry started with $30 \mathrm{ml}$ of simulant which was added as 35.4 grams slurry.

\subsection{SIMULANT FOAMING VS. Q2-3183A ANTIFOAM CONCENTRATION}

An antifoam solution containing 10,000 ppm Dow Corning Q2-3183A in water was made. This same solution was used for all experiments in this report. The antifoam solution was added to the slurry contained in the foam column (slurry volume was controlled at $30 \mathrm{~mL}$ ) prior to onset of foaming. In addition, the antifoam was added to existing foam in a foaming solution subjected to air sparging, and the foam collapse was followed. 
The baseline performance of the simulant and how its foaminess was affected by various concentrations of the Q2-3183A antifoam in the slurry was established. Foaminess was measured at four air flowrates as described in section 4.1. After measuring the foaminess of the slurry without antifoam, 70 ppm increments of antifoam were added to the slurry, and the foaminess was measured at each increment, up to $350 \mathrm{ppm}$ antifoam. From $350 \mathrm{ppm}$ antifoam on, $175 \mathrm{ppm}$ increments of antifoam were added to the slurry, and the foaminess was measured at each increment, up to 1050 ppm antifoam. Figure 6 shows the results of this experiment.

Figure 6. Foaminess of 12.9 wt \% UDS Slurry vs. Q2-3183A Concentration

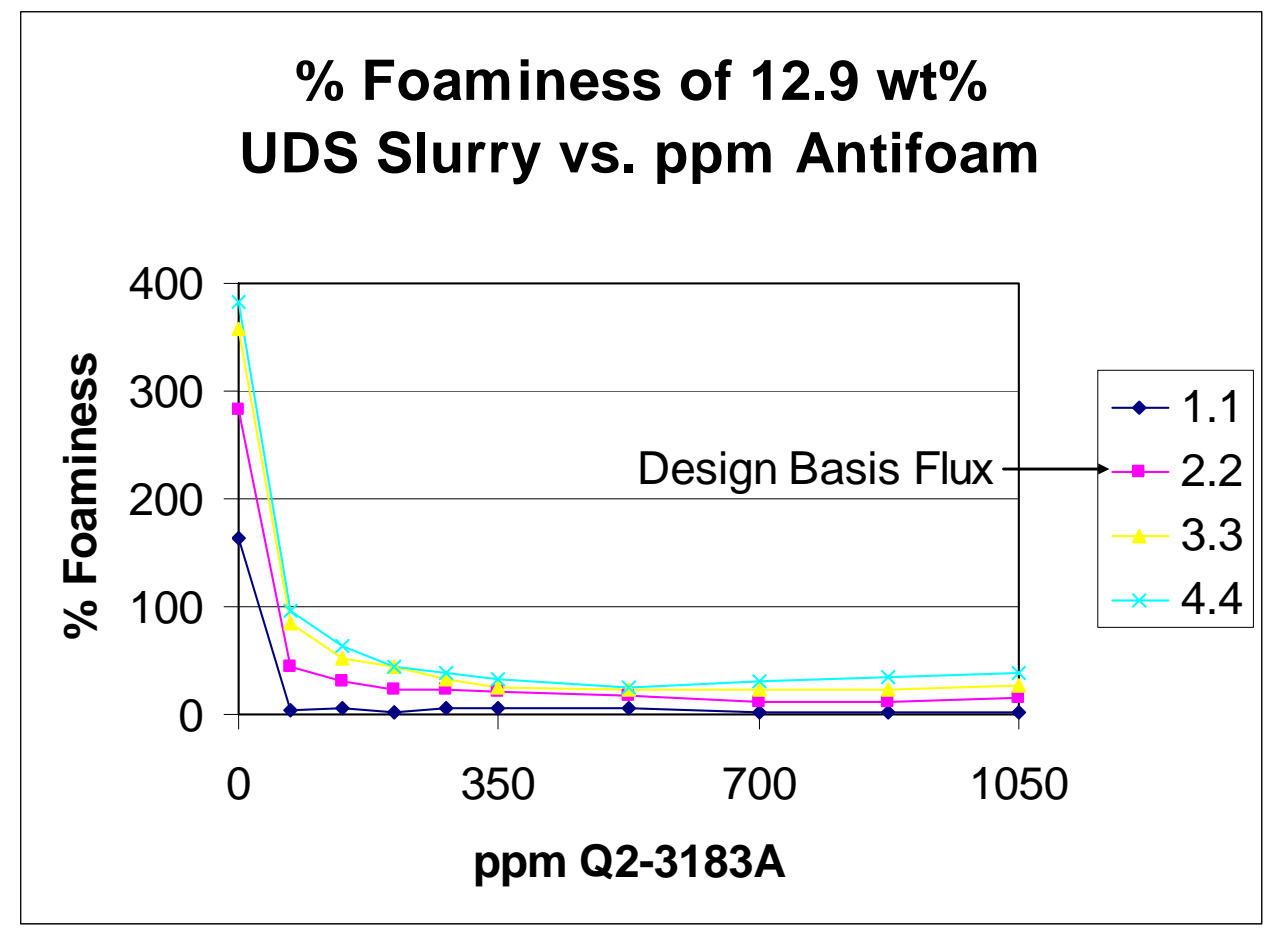

These results show the simulant foams in a manner that is consistent with the AY102 simulant used previously by SRNL researchers ${ }^{3}$. However, the magnitude of the foam is not as high as the AY102 simulant used previously. While the origin (both used materials from the SIPP) of both simulants is the same, the age and exact make-up of the simulants is different. However for the purposes of this study, the foaminess of the simulant turned out to be somewhat insignificant compared to the foam caused by the oxidative leaching process (See Section 4.5) 


\subsection{FOAMING VS. CAUSTIC LEACHING AND WASHING}

Caustic leaching and washing of $50 \mathrm{ml}$ of slurry was performed as discussed in section 4.1 using the apparatus shown in Figure 3". Upon completion of these processes, $30 \mathrm{ml}$ of the treated slurry were added to the foam column (shown in Figure 1) to measure foaminess. Figure 7 shows the effect that caustic leaching and washing has on foaminess at the design basis plant air flux of $2.2 \mathrm{ft}^{3} / \mathrm{min} / \mathrm{ft}^{2}$.

Figure 7. Foaminess vs. Caustic Leach and Washing at Air Flux of $2.2 \mathrm{ft}^{3} / \mathrm{min} / \mathrm{ft}^{2}$

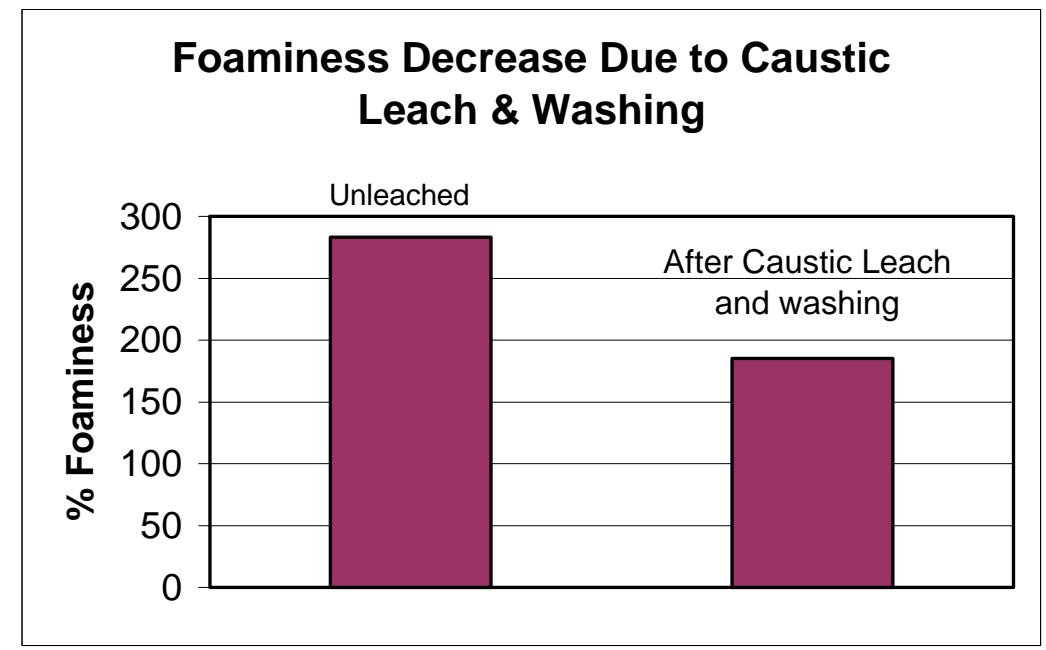

Figure 7 shows that the foaminess of the slurry is reduced from $283 \%$ down to $185 \%$. The $283 \%$ foaminess comes from Figure 6 where the condition is $2.2 \mathrm{ft} 3 / \mathrm{min} / \mathrm{ft}^{2}$ flux and no antifoam. The reduction in foaminess is probably due to a reduction in the dissolved solids content of the supernate fraction along with a reduction in the undissolved solids content (see Figure 4 and Figure 5). The reduction could also be due to a dilution of the surfactant concentration in the simulant.

\subsection{FOAMING VS. OXIDATIVE LEACHING \& WASHING VS. ppm Q2-3183A}

The oxidative leach test results will be described in the following order:

1. High Insoluble Cr, No Antifoam

2. High Insoluble Cr, with Antifoam.

3. Low Insoluble Cr, No Antifoam

4. Low Insoluble Cr, with Antifoam 
WSRC-TR-2005-00263, REV. 0

SRNL-RPP-2005-00039, REV. 0

\section{Oxidative Leaching and Washing of High Cr Slurry with No Antifoam}

Two runs were performed as described in section 4.1 of this report. The oxidative leach with high Cr used $1.8 \mathrm{ml}$ of $1 \mathrm{M} \mathrm{NaMnO}_{4}$ solution. Run 1 had 70 ppm Q2-3183A added at the end of the oxidative leach, but did not undergo washing. Figure 8 shows the results for the design basis plant air flux of $2.2 \mathrm{ft}^{3} / \mathrm{min} / \mathrm{ft}^{2}$.

Figure 8. Oxidative Leaching and Washing of High Cr Slurry with No Antifoam

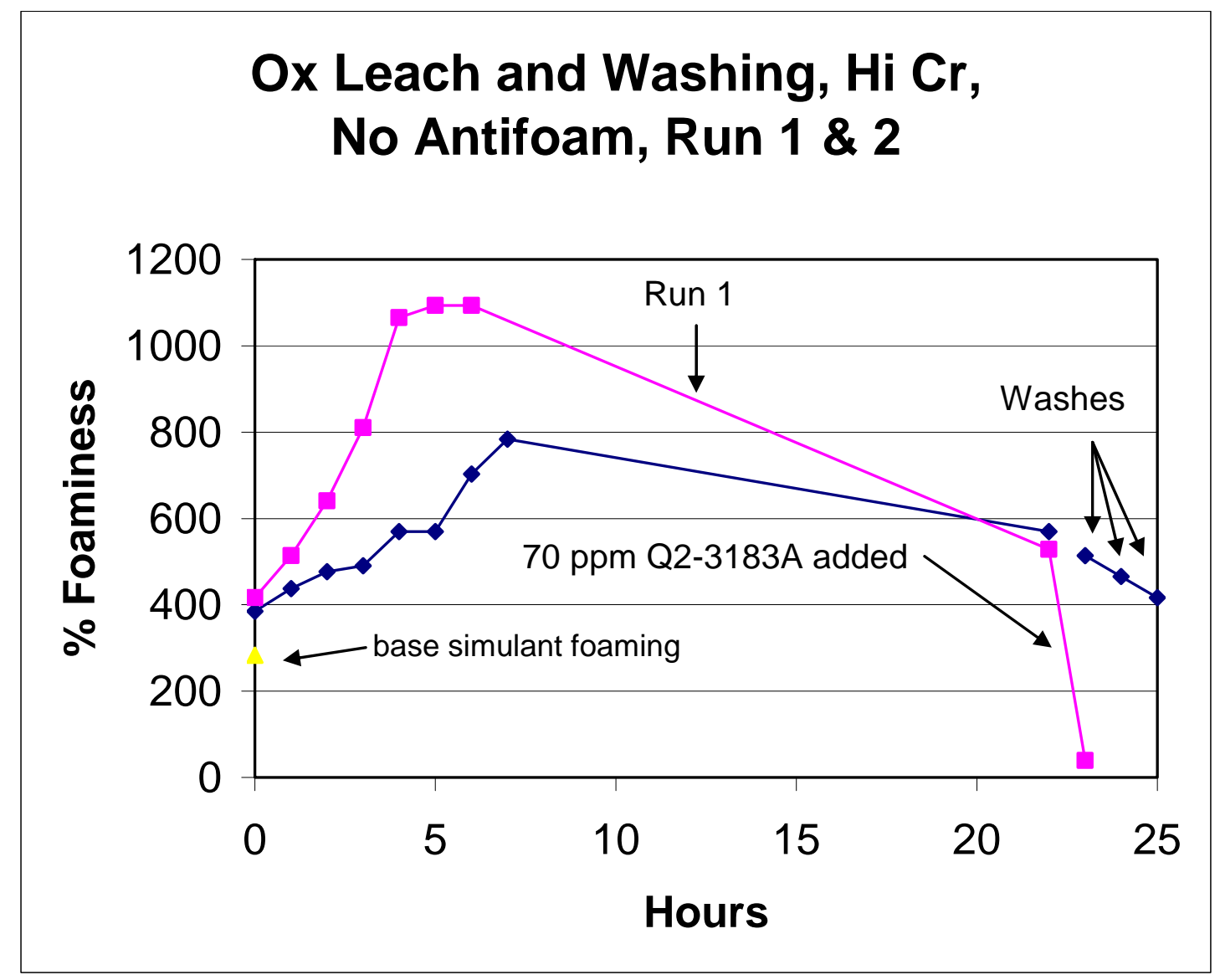

Though there is a significant difference in maximum foaminess between the two runs it is notable that they both began the oxidative leach near $400 \%$ and ended the oxidative leach near $550 \%$. Compare to $283 \%$ foaminess for basic slurry. Washing lowered run 2 foaminess down to $400 \%$ and a 70 ppm addition of antifoam lowered run 1 foaminess down to $40 \%$. The run 2 wash 1 supernate initially appeared a clear dark purple. After sitting for an hour undisturbed, it turned to a clear dark green. The run 2 wash 2 supernate appeared a clear light green. The remainder of the wash supernates were clear yellow. 


\section{Oxidative Leaching and Washing of High Cr Slurry with Antifoam}

Two runs were performed as described in section 4.1 of this report. The oxidative leach with high Cr used $1.8 \mathrm{ml}$ of $1 \mathrm{M} \mathrm{NaMnO}_{4}$ solution. Run 1 began with $350 \mathrm{ppm}$ Q2-3183A and run 2 began with 1280 ppm Q2-3183A. Run 1 received five additional 70 ppm Q2-3183A additions during the first five hours of the oxidative leaching. Both runs received the standard wash. Run 2 received two additional 70 ppm Q2-3183A additions after the washes. Figure 9 shows the results for the design basis plant air flux of $2.2 \mathrm{ft}^{3} / \mathrm{min} / \mathrm{ft}^{2}$.

Figure 9. Oxidative Leaching and Washing of High Cr Slurry with Antifoam

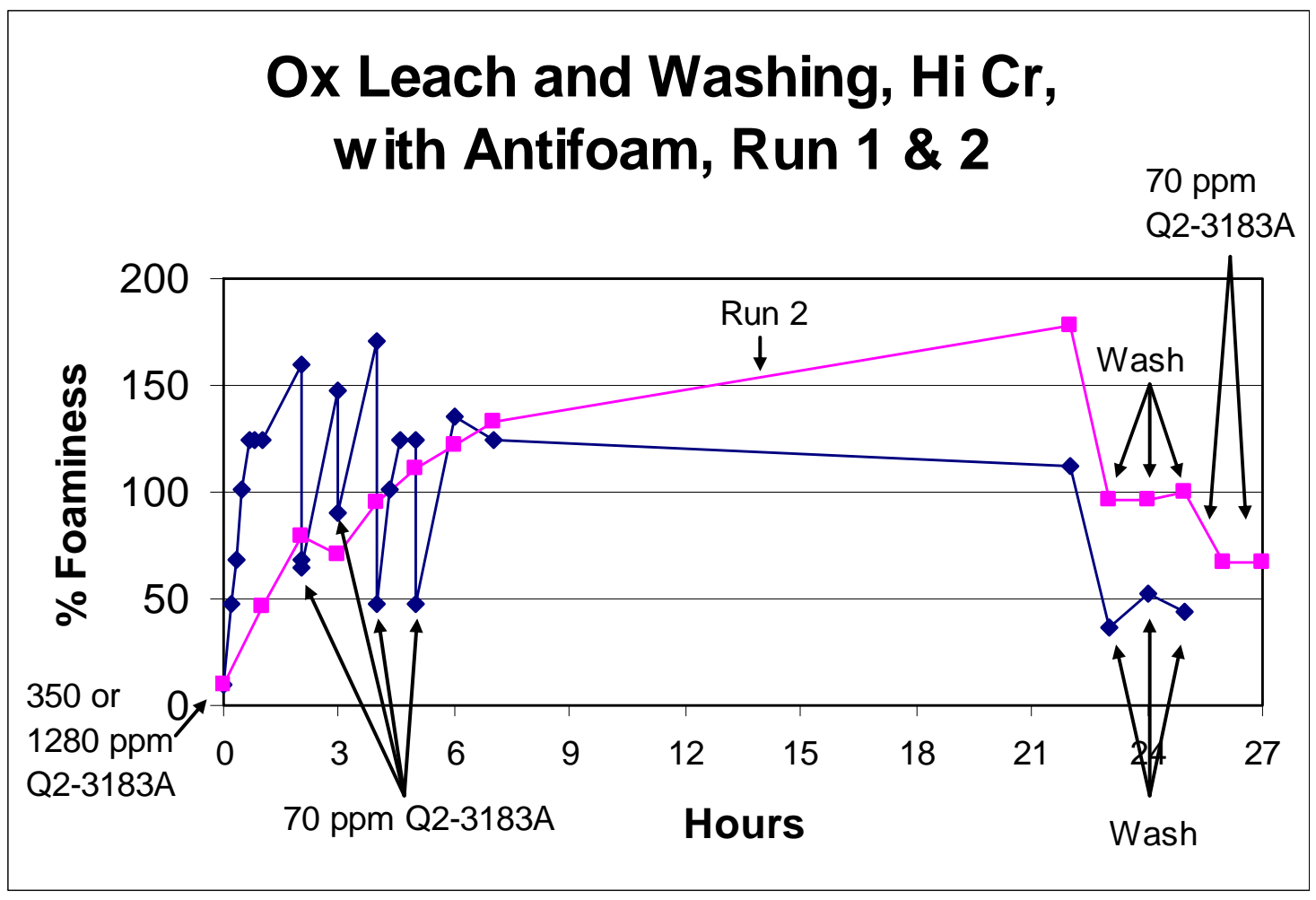

The $\mathrm{NaMnO}_{4}$ impaired the antifoam's effectiveness in both runs, possibly due to degradation of the antifoam by the highly oxidizing permanganate. Less of the Q2-3183A was used in run 1 (2 $\mathrm{ml}$ of $10000 \mathrm{ppm}$ Q2-3183A) than in run 2 (4.2 ml of $10000 \mathrm{ppm}$ Q2-3183A). The washes reduced foaminess in both runs. A cloudy yellow supernate was observed after the first wash and all subsequent washes. The two additional 70 ppm Q2-3183A additions after the washes to run 2 only provided a marginal reduction in foaminess. 
WSRC-TR-2005-00263, REV. 0

SRNL-RPP-2005-00039, REV. 0

Oxidative Leaching and Washing of High Cr Slurry at Various Air Fluxes

Figure 10 is run 2 from Figure 9 on "Oxidative Leaching and Washing of High Cr Slurry with Antifoam” shown as a function of air sparge rate. The air fluxes range from 1.1 to $4.4 \mathrm{ft}^{3} / \mathrm{min} / \mathrm{ft}^{2}$.

Figure 10. Oxidative Leaching and Washing of High Cr Slurry at Various Air Fluxes

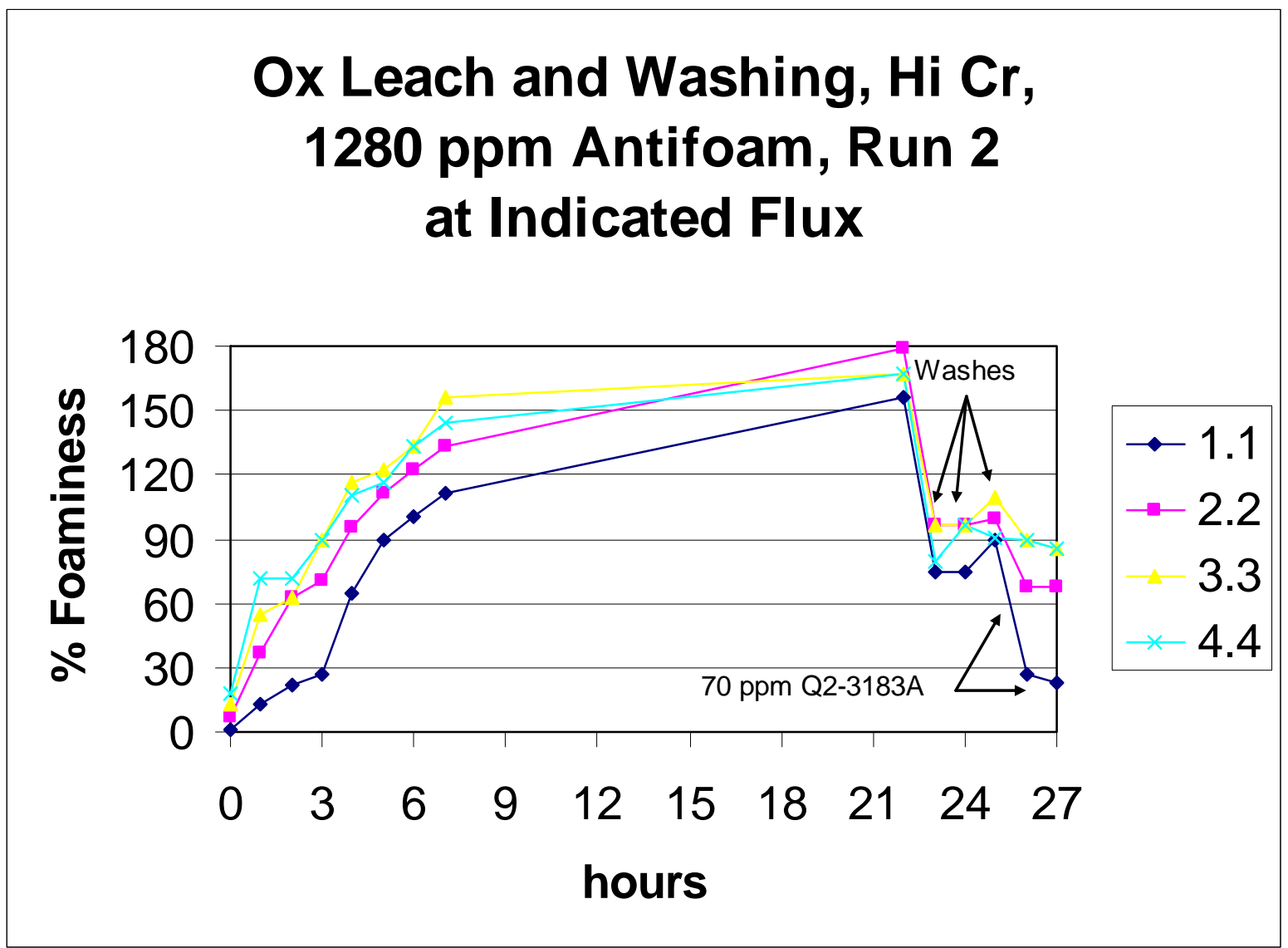

In general, more air bubbled through the slurry produces a higher foam height. This same phenomenon can also been observed in Figure 6. 


\section{Oxidative Leaching and Washing of Low Cr Slurry with No Antifoam}

Two runs were performed simultaneously in two adjoining foam columns and were performed as described in section 4.1 of this report. Due to a calculation error performed in the lab, only $0.3 \mathrm{ml}$ of $1 \mathrm{M} \mathrm{NaMnO}$ s solution was added to the slurry instead of the required $0.47 \mathrm{ml}$. Thus, enough permanganate was added to treat $2 \mathrm{mg} \mathrm{Cr} / \mathrm{g}$ solids rather than $3.17 \mathrm{mg} \mathrm{Cr} / \mathrm{g}$ solids actually in the slurry. Figure 11 shows the results for the design basis plant air flux of $2.2 \mathrm{ft}^{3} / \mathrm{min} / \mathrm{ft}^{2}$.

Figure 11. Oxidative Leaching and Washing of Low Cr Slurry with No Antifoam

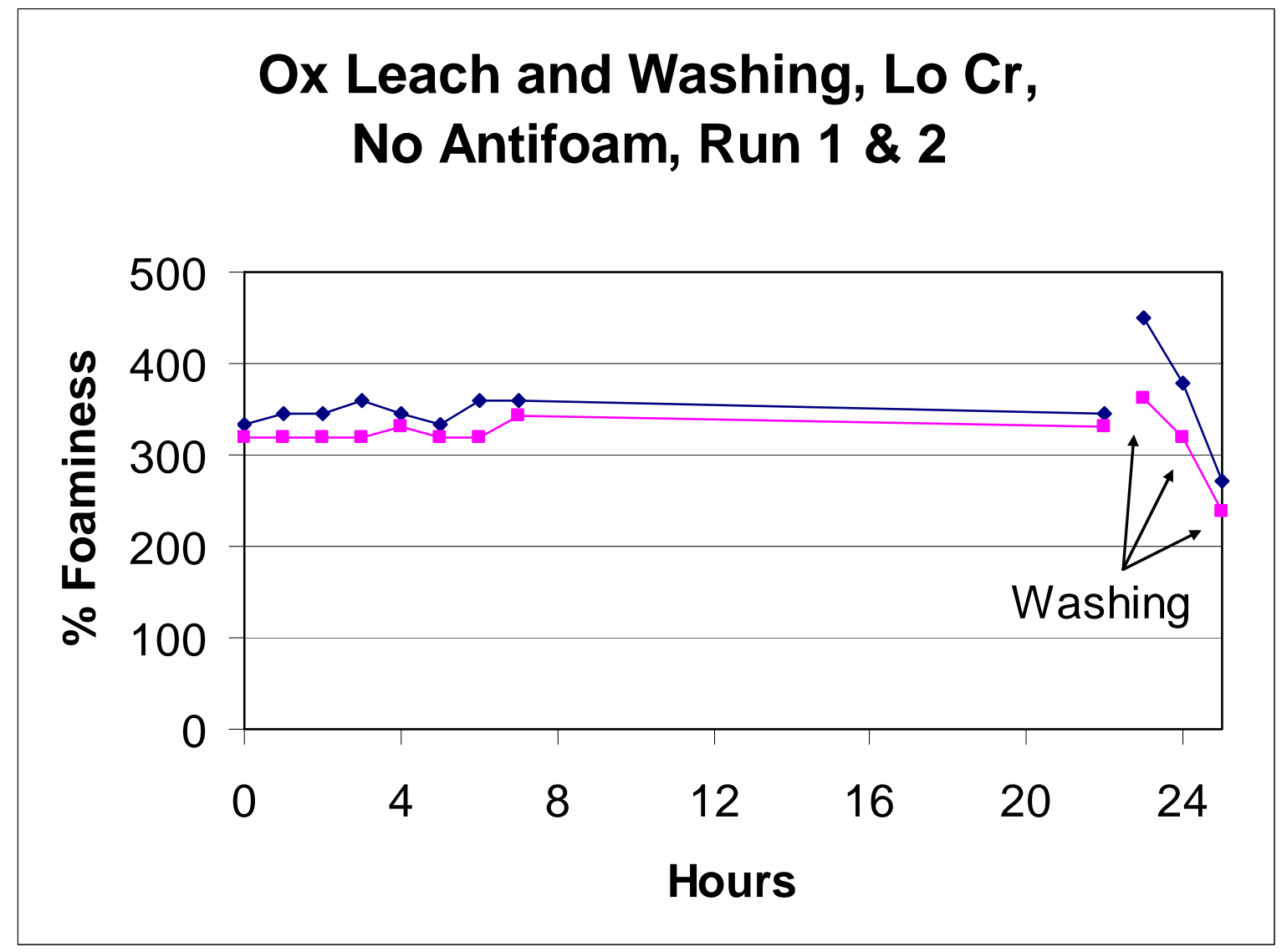

An average foaminess of $336 \%$ shows a slight increase in foaminess versus the $283 \%$ for untreated slurry shown in Figure 7. A clear yellow supernate was observed after the first wash and all subsequent washes. Foaminess first increased due to washing, then decreased from further washing. 
WSRC-TR-2005-00263, REV. 0

SRNL-RPP-2005-00039, REV. 0

\section{Oxidative Leaching and Washing of Low Cr Slurry with Antifoam}

Two runs were performed simultaneously in two adjoining foam columns and were performed as described in section 4.1 of this report. Since the oxidative leach with low $\mathrm{Cr}$ and no antifoam used $0.3 \mathrm{ml}$ of $1 \mathrm{M} \mathrm{NaMnO}_{4}$ solution, the same was added in these experiments for comparative results. Antifoam (350 ppm) was added at the start of the runs. Two successive additions of $70 \mathrm{ppm}$ antifoam were added at the end of the oxidative leach, but prior to washing. Figure 12 shows the results for the design basis plant air flux of $2.2 \mathrm{ft}^{3} / \mathrm{min} / \mathrm{ft}^{2}$.

Figure 12. Oxidative Leaching and Washing of Low Cr Slurry with 350 ppm Antifoam

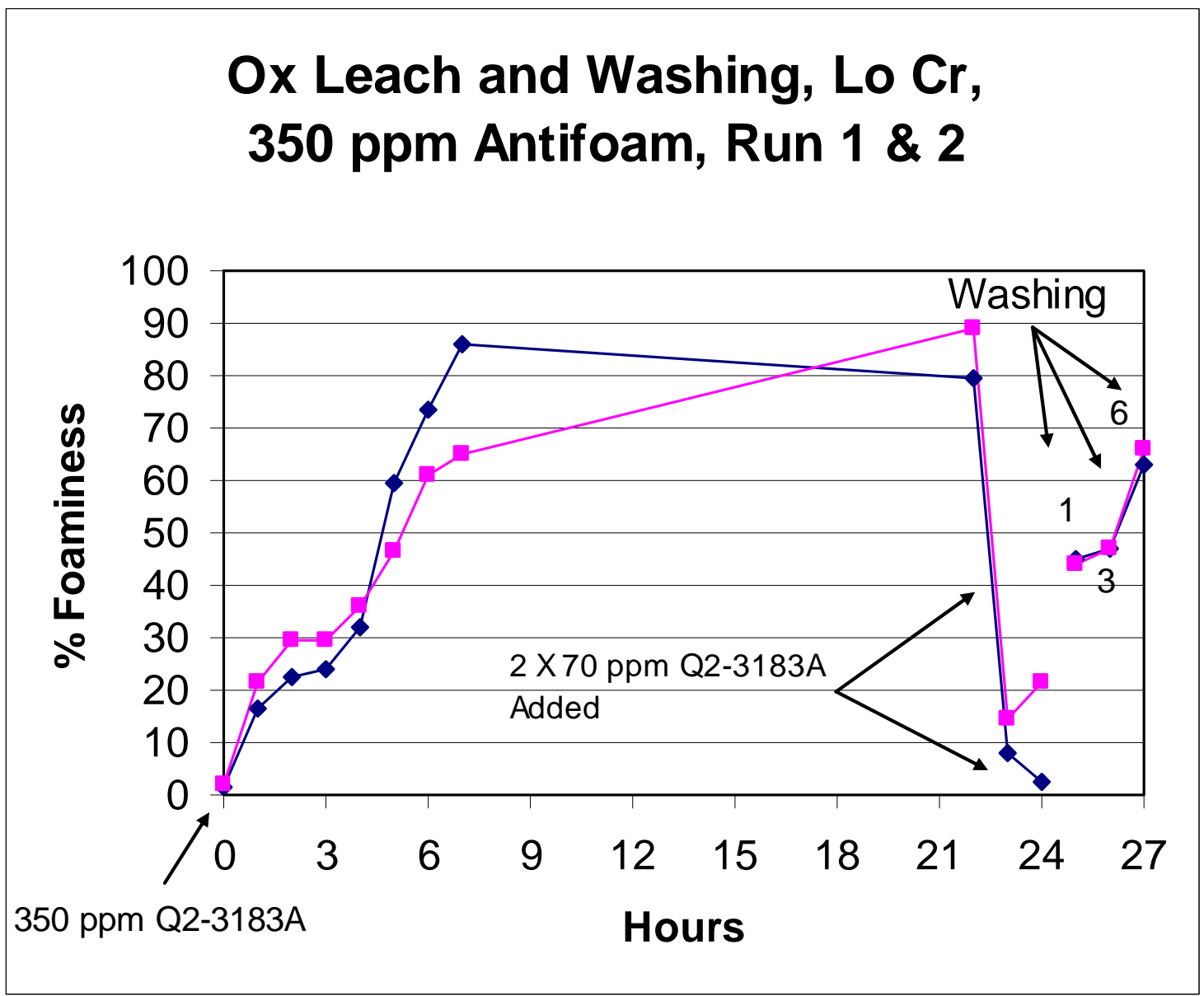

The average peak foaminess at the end of the oxidative leach was $85 \%$ which compares favorably to the average foaminess of $336 \%$ for treated slurry without antifoam shown in Figure 11. A clear yellow supernate was observed after the first wash and all subsequent washes. Foaminess increased due to washing probably due to the dilution and removal of the antifoam. 
WSRC-TR-2005-00263, REV. 0

SRNL-RPP-2005-00039, REV. 0

\subsection{FOAMING VS. WT\% UDS IN HIGH CHROME SLURRY}

Foaminess of the high chrome slurry was tested at three different concentrations of undissolved solids (UDS). These concentrations were 8, 15, and $20 \mathrm{wt} \%$ UDS. The effectiveness of the Q2-3183A antifoam was tested for each of these cases. Figure 13 and Figure 14 show the results of these tests for the design basis air flux of $2.2 \mathrm{ft}^{3} / \mathrm{min} / \mathrm{ft}^{2}$.

Figure 13. Wt\% UDS vs Foaminess vs Q2-3183A

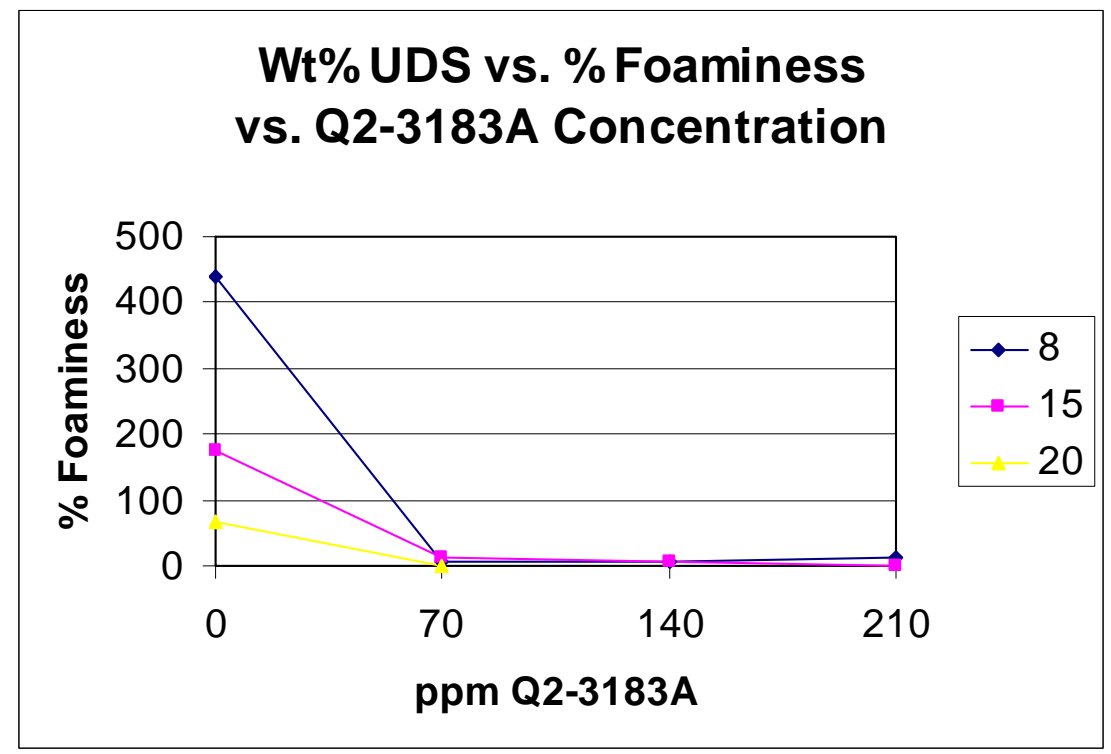

Figure 14. Wt\% UDS vs Foaminess vs Q2-3183A, Zero Point Removed

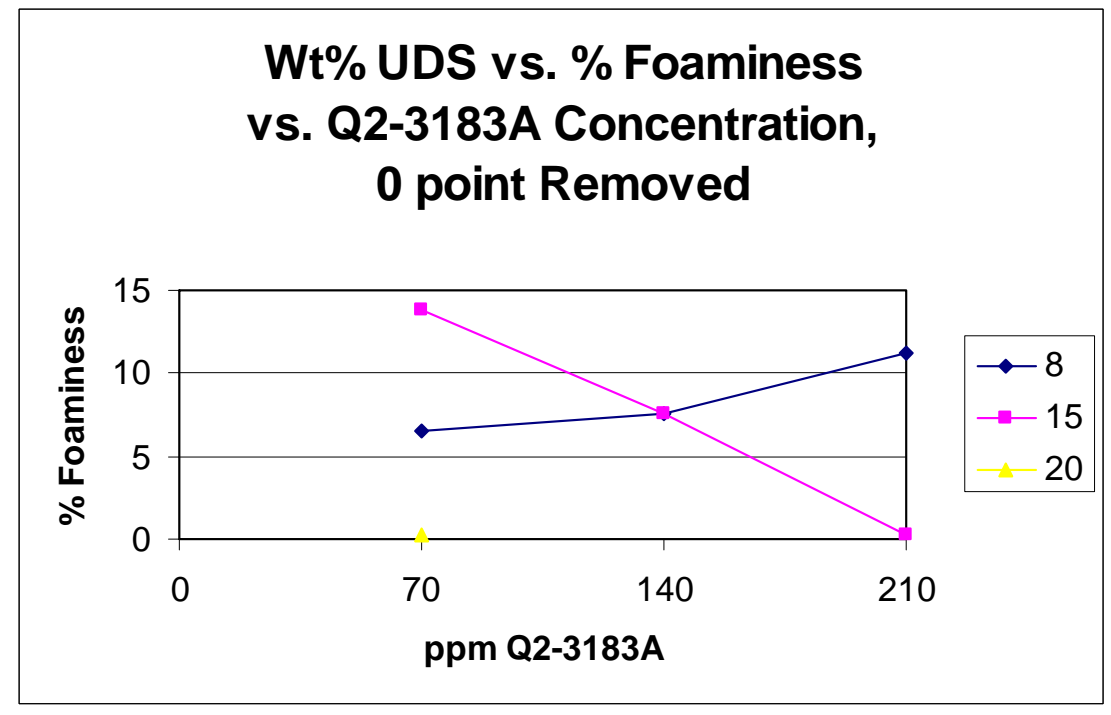


The much reduced foaminess in the higher solids concentrations are corroborated by these tests versus those shown in Figure 5. The antifoam was quite effective at reducing the foaming at all three solids concentrations. At 70 ppm Q2-3183A, the $20 \mathrm{wt} \%$ UDS slurry foam's percent foaminess was reduced to $0 \%$. At $210 \mathrm{ppm}$ Q2-3183A, the $15 \mathrm{wt} \%$ UDS slurry foam's percent foaminess was reduced to $0 \%$. At $70 \mathrm{ppm}$ Q2-3183A, the $8 \mathrm{wt} \%$ UDS slurry foam's percent foaminess was reduced to 6\%. The $8 \mathrm{wt} \%$ UDS slurry exhibited an odd behavior of increasing foaminess after 70 ppm Q2-3183A.

The high initial result for the $8 \mathrm{wt} \%$ UDS condition contradicts the result for the nearly same condition shown in Figure 5. The odd behavior of the $8 \mathrm{wt} \%$ slurry is probably due to a difference in how it was made. It was expected that a mixture of the $12.9 \mathrm{wt} \%$ slurry mixed with wash 2 permeate to form an $8 \mathrm{wt} \%$ slurry would act nearly the same as if supernate from the 12.9 wt\% slurry itself was used. However, the slurry foamed much more than expected and does not compare favorably with similar results for the nearly same condition shown in Figure 5.

Thus $12 \mathrm{ml}$ of the wash 2 permeate was mixed into $18 \mathrm{ml}$ of the $12.9 \mathrm{wt} \%$ base solution to form an $8 \mathrm{wt} \%$ UDS solution. The $8 \mathrm{wt} \%$ data point should be ignored with relation to all other data in this report. This result does show that foaminess can be affected by differences in simulant make-up.

\subsection{FOAMING VS. CAUSTIC LEACH \& OXIDATIVE LEACH AT BASELINE \& IDLE SPARGER FLUXES}

If the oxidative leach is performed at ambient temperature, then the process pump can be used for agitation of the tank material and the sparger can be left at an idle flowrate to prevent pluggage in the sparger tube. These tests measured percent foaminess at the idle sparger air flux of $0.22 \mathrm{ft}^{3} / \mathrm{min} / \mathrm{ft}^{2}$ and at the baseline sparger air flux of $2.2 \mathrm{ft}^{3} / \mathrm{min} / \mathrm{ft}^{2}$. To simulate pump mixing, a peristaltic pump recirculated the slurry through the foam column at a rate of approximately one total slurry volume per ten minutes.

The 12.9 wt $\%$ UDS simulant had $\mathrm{Cr}_{2} \mathrm{O}_{3}$ added so that the simulant had $12 \mathrm{mg} \mathrm{Cr} / \mathrm{g}$ slurry, which is considered the highest expected Cr concentration for Hanford waste. Q2-3183A antifoam was added just prior to the caustic leaching such that there was $350 \mathrm{ppm}$ antifoam in the slurry. After performing the caustic leach and cooling the material down to ambient temperature, the $100 \mathrm{ml}$ of caustic leached slurry was washed six times with $9 \mathrm{ml}$ of $0.01 \mathrm{M}$ $\mathrm{NaOH}$. A centrifuge was used to separate and remove supernate for each wash. The $\%$ foaminess was measured at the idle flux $\left(0.22 \mathrm{ft}^{3} / \mathrm{min} / \mathrm{ft}^{2}\right)$ and at the baseline flux $\left(2.2 \mathrm{ft}^{3} / \mathrm{min} / \mathrm{ft}^{2}\right)$ after the caustic leach and each wash. The results are shown in Figure 15. 
Figure 15. Foaminess After Caustic Leach and Washes

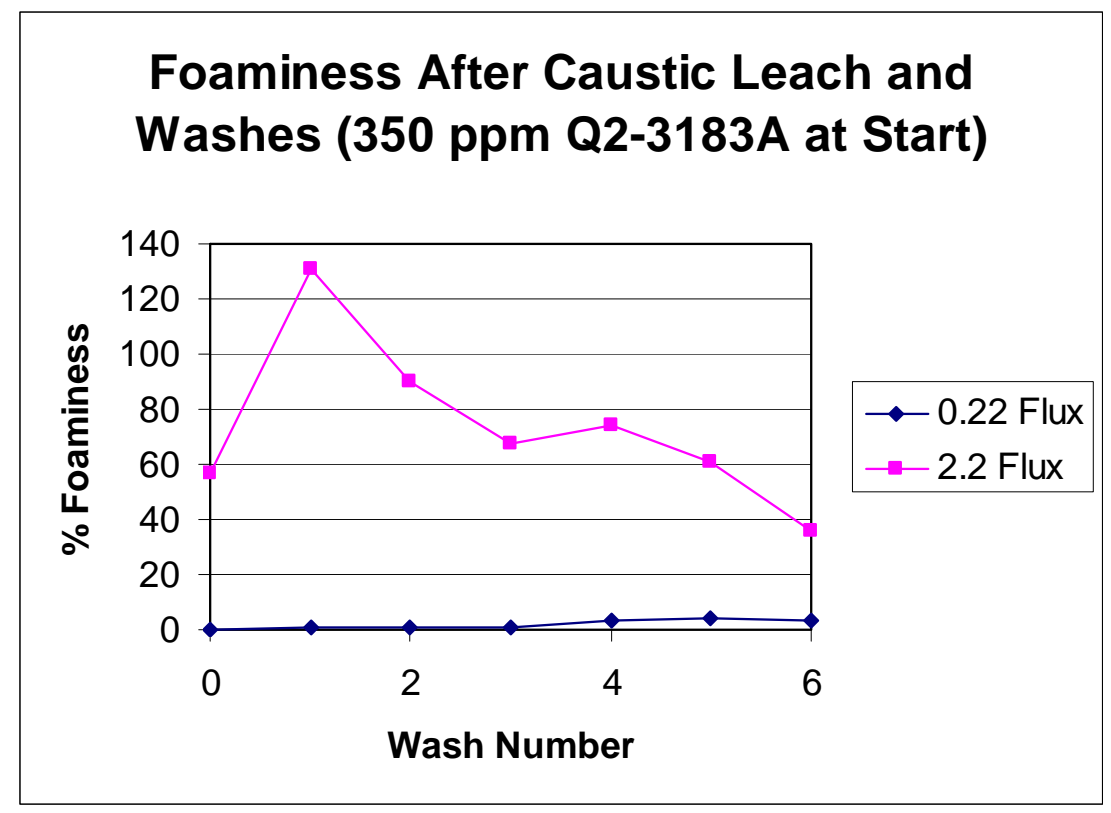

As seen in Figure 15, the caustic leach and washing reduces the foaminess of the slurry. In this case it went from 56\% down to 36\% foaminess. Figure 7 showed a reduction from $283 \%$ down to $185 \%$ foaminess with no antifoam. The percentage of drop in percentage foaminess is very close between the two runs (35\% versus $34 \%$ respectively). The difference in magnitude is due to the addition of antifoam in this latest run.

Two comparative runs using the slurry from the caustic leach and washing were then run through an oxidative leach. The first run was performed without further antifoam added. The second run had an additional 350 ppm of Q2-3183A added just prior to the start of the oxidative leaching. Each reaction ran for 6 hours at ambient temperature. Each $32 \mathrm{ml}$ of slurry was constantly being recirculated at $4 \mathrm{ml} / \mathrm{min}$ to mimic plant recirculation. The sparger air was set at $0.22 \mathrm{ft}^{3} / \mathrm{min} / \mathrm{ft}^{2}$ throughout each run. It was raised to $2.2 \mathrm{ft}^{3} / \mathrm{min} / \mathrm{ft}^{2}$ once per hour to get a baseline foaminess reading. The results from these runs are shown in Figure 16 and Figure 17. 
Figure 16. Foaminess During Oxidative Leach at $2.2 \mathrm{ft}^{3} / \mathrm{min} / \mathrm{ft}^{2}$

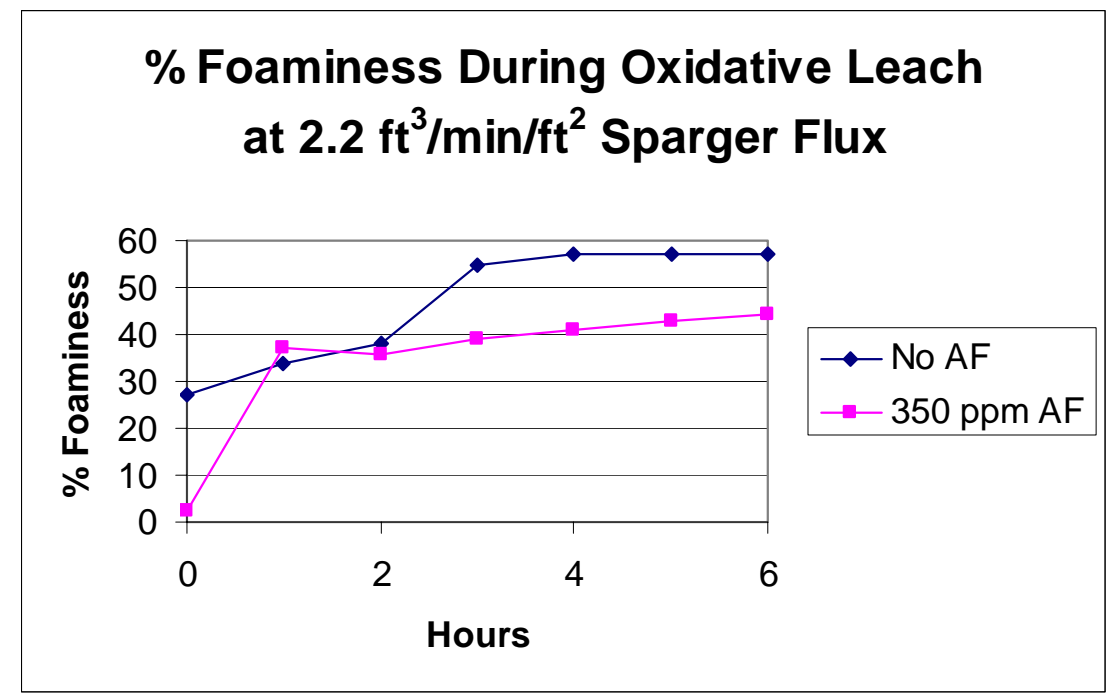

At the baseline sparger air flux, the added $350 \mathrm{ppm}$ of Q2-3183A antifoam, (in addition to the 350 ppm Q2-3183A added at the start of the caustic leach), only reduced the percentage foam height by an average of $14.75 \%$ from the third hour to the sixth hour of the reaction.

Figure 17. Foaminess During Oxidative Leach at $0.22 \mathrm{ft}^{3} / \mathrm{min} / \mathrm{ft}^{2}$

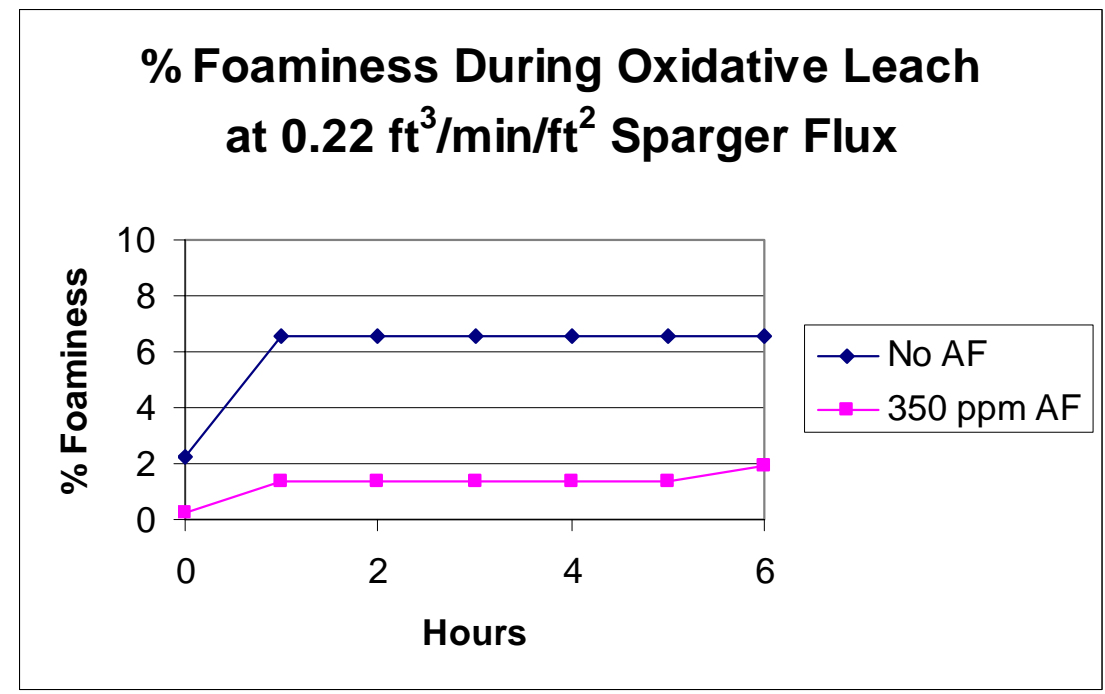

The added $350 \mathrm{ppm}$ of Q2-3183A had a minimal effect on reducing the percentage foam at the idle sparger air flow rate because there was so little foam formed at that condition. 


\subsection{EFFECTIVENESS OF ANTIFOAMS Q2-3183A, Q2-3315, 1520US, AND IIT-747 DURING OXIDATIVE LEACHING}

These tests were performed to determine if other antifoams might prove to be more effective at reducing the foam during the oxidative leaching process. Unfortunately, the supply of slurry simulant, used for all previous tests discussed in this report, was consumed. Therefore, another batch of simulant was made using the same base materials as the original simulant. However, the new batch of simulant did not exhibit the same foaminess as the original batch of simulant. Therefore, all data in this section of the report is not comparable to the data in the rest of the report. A comparison of the new $12.9 \mathrm{wt} \%$ AY-102 slurry versus the original 12.9 wt\% AY-102 slurry is shown in Figure 18.

Figure 18. Difference in AY-102 Simulant Batches

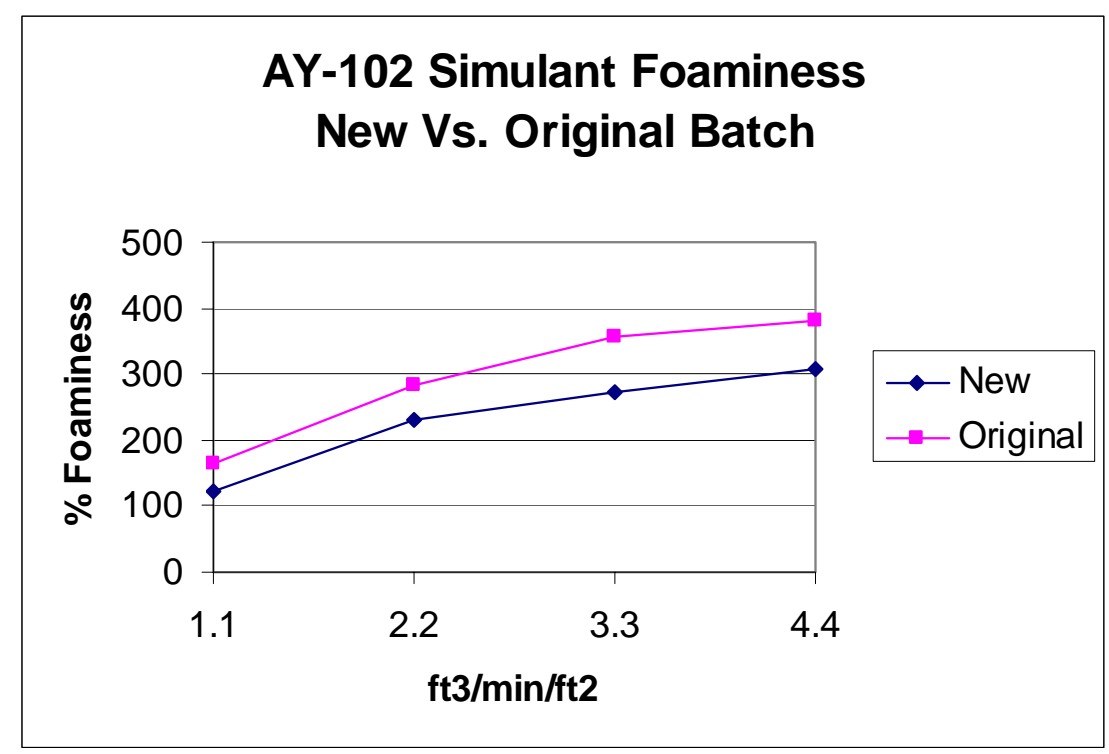

Since the new simulant was different (less foamy) than the original simulant, a run was performed with the Q2-3183A and the new simulant for comparison with the other antifoams in this section.

The foam column had a recirculating peristaltic pump connected up to it as shown in Figure 19. This was added to simulate pump mixing in the process tank while the sparger air is at idle flow. 
Figure 19. Foam Column with Recirculation Loop

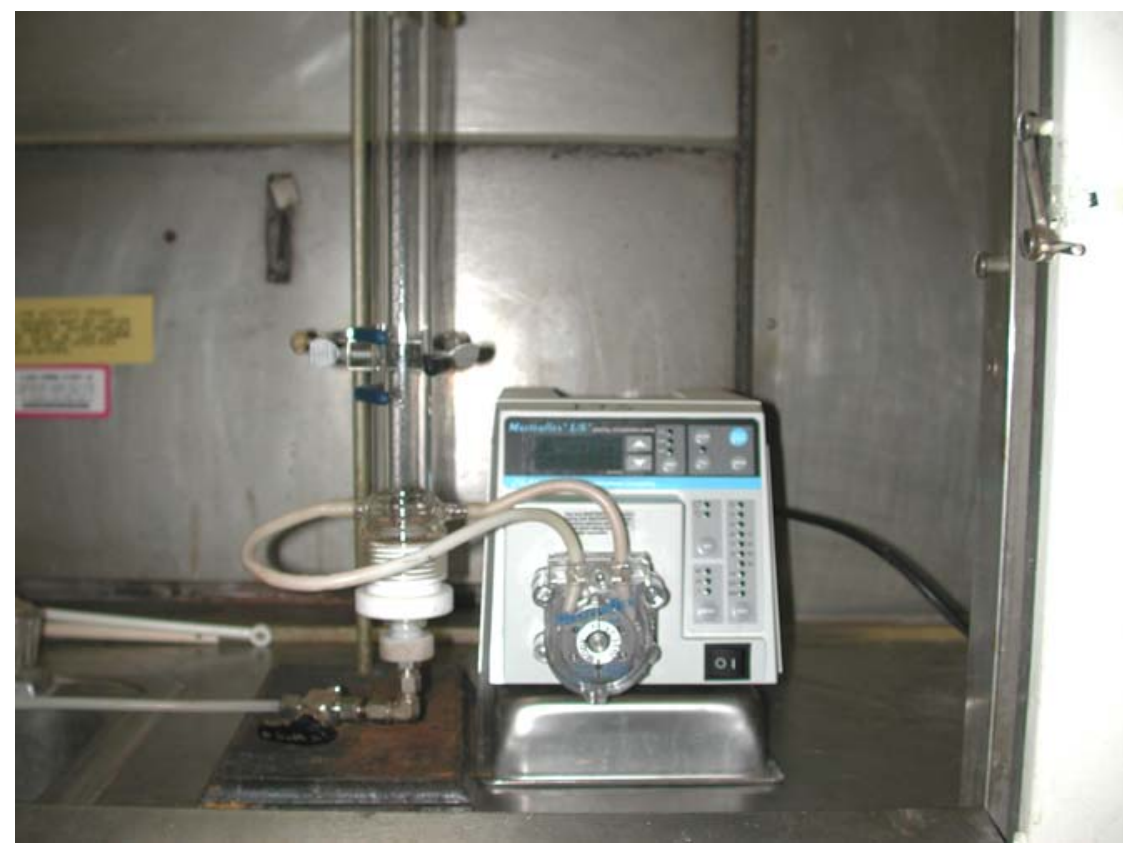

The process for these tests was performed as follows:

1. Add $41.5 \mathrm{ml}$ of AY-102 slurry to the foam column. Note that this volume gives the same starting liquid level in the foam column as $30 \mathrm{ml}$ did with a foam column that did not have a recirculating pump loop.

2. Add Q2-3183A antifoam to reach $70 \mathrm{ppm}$ concentration in slurry.

3. Add (antifoam under investigation) to reach $350 \mathrm{ppm}$ concentration in slurry.

4. Run pump on prime (high speed) until all air is out of pump lines (no bubbles appear from line discharge).

5. RECORD liquid level.

6. Set air flux to $0.22 \mathrm{ft}^{3} / \mathrm{min} / \mathrm{ft}^{2}$.

7. RECORD FOAM height.

8. STOP air flow.

9. ADD $1 \mathrm{M} \mathrm{NaMnO} 4$ solution.

10. RECORD liquid level.

11. Run pump on prime (high speed) for 1 minute to thoroughly mix permanganate into slurry.

12. Set pump flow to $5 \mathrm{ml} / \mathrm{min}$.

13. Set air flux to $0.22 \mathrm{ft}^{3} / \mathrm{min} / \mathrm{ft}^{2}$.

14. RECORD FOAM height.

15. RECORD FOAM height every hour for remainder of shift (at least 6 hours). Also measure foam height at air flux of $2.2 \mathrm{ft}^{3} / \mathrm{min} / \mathrm{ft}^{2}$ once per hour.

16. ADD $70 \mathrm{ppm}$ of antifoam after the $6^{\text {th }}$ hour. RECORD FOAM height after antifoam addition. Also measure foam height at air flux of $2.2 \mathrm{ft}^{3} / \mathrm{min} / \mathrm{ft}^{2}$.

The results of performing this test for antifoams Q2-3183A, 1520US, Bourgman 747, and Q23315 are shown in Figure 20. 
WSRC-TR-2005-00263, REV. 0

SRNL-RPP-2005-00039, REV. 0

Figure 20. Foaminess During Oxidative Leach for Various Antifoams at 0.22 Sparger Flux

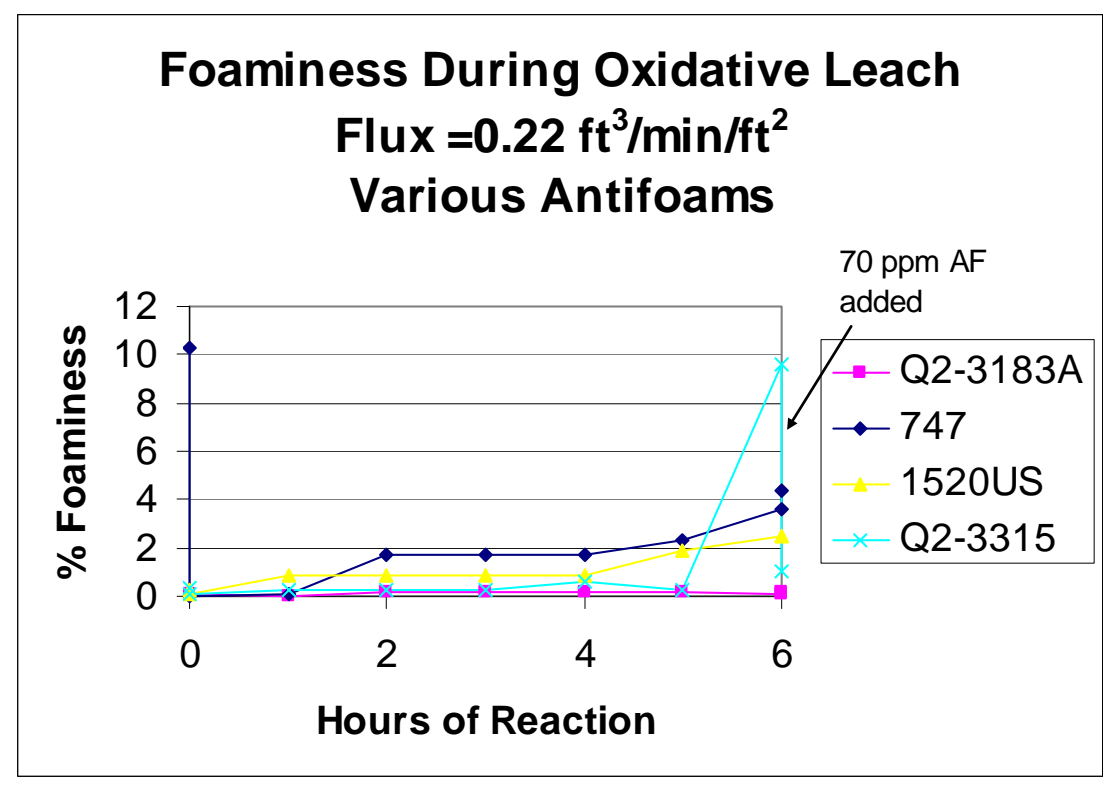

Figure 21. Foaminess During Oxidative Leach for Various Antifoams at 2.2 Sparger Flux

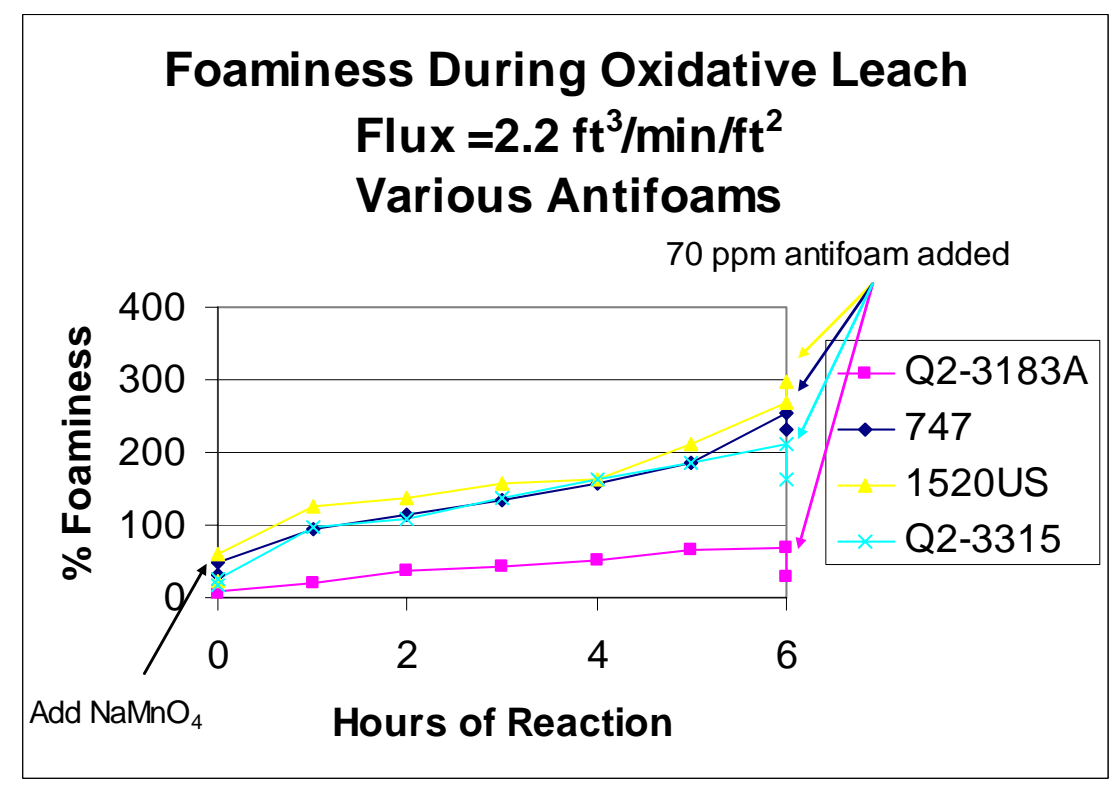

Though the difference in foaming was insignificant between the four antifoams at the idle sparger rate of $0.22 \mathrm{ft}^{3} / \mathrm{min} / \mathrm{ft}^{2}$, once the sparger rate was increased to the baseline rate of $2.2 \mathrm{ft}^{3} / \mathrm{min} / \mathrm{ft}^{2}$, the Q2-3383A antifoam showed much better performance than the other three antifoams tested. 
WSRC-TR-2005-00263, REV. 0

SRNL-RPP-2005-00039, REV. 0

\subsection{DISCUSSION / CONCLUSIONS}

The Dow Corning Q2-3183A antifoam was effective at reducing the foaminess of the simulant as shown in Figure 6 when the spargers are either at idling or sparging condition, but not when oxidative leaching and full sparging are in progress.

Caustic leaching and washing of the simulant reduced the foaminess of the simulant from $283 \%$ down to $185 \%$. This is probably due to a reduction in both the undissolved solids (due to the caustic leach) and dissolved solids (due to the washing). Thus the caustic leach and wash was not performed on the simulant used for the oxidative foaming tests.

The oxidative leaching tests were performed for the following conditions:

1. High insoluble Cr, No Antifoam

2. High insoluble $\mathrm{Cr}$, with Antifoam

3. Low insoluble Cr, No Antifoam

4. Low insoluble Cr, with Antifoam.

Oxidative leaching of $\mathrm{Cr}$ is accomplished with the addition of $1 \mathrm{M} \mathrm{NaMnO}$ at ambient temperature. Tests 1 and 3 (no antifoam added, see Figure 8 and Figure 11) both showed an increase in foaminess over slurry with no $\mathrm{NaMnO}_{4}$ added. Test 1 , high insoluble $\mathrm{Cr}$ simulant with no antifoam showed considerably more foaminess ( $>1000 \%$ vs. a baseline simulant foaminess of 283\%) due to the $6 \mathrm{X}$ larger addition of $\mathrm{NaMnO}_{4}$. The maximum foam height occurred more than five hours after the addition of $\mathrm{NaMnO}_{4}$. Tests 2 and 4 (High and Low Insoluble $\mathrm{Cr}$, antifoam added, Figure 9 and Figure 12) showed a rapid degradation in the effectiveness of the antifoam, possibly due to reaction with the $\mathrm{NaMnO}_{4}$ solution. The amount of foam produced by the oxidative leaching process is a strong function of the total $\mathrm{NaMnO}_{4}$ added to the vessel. While not completely understood at this time, the mechanism causing the formation of foam during the oxidative leaching process is believed to be caused by insoluble Mn particles. A secondary cause for foaming in this process is believed to be caused by an unknown surfactant that is present in the base simulant.

The antifoam was not very effective at reducing the foam during the baseline oxidative leaching process. The antifoam reduced the foaminess to a maximum of $180 \%$ and $90 \%$ for the high and low insoluble $\mathrm{Cr}$ simulants, respectively. Previous SRNL foam column experiments, that were conducted to simulant air sparge tank systems, showed an initial charge of $345 \mathrm{ppm}$ antifoam reduced the foaminess of a Hanford tank waste sample, AN-104 with $9 \mathrm{wt} \%$ simulant solids, to $13 \%{ }^{3}$ foam. Therefore, Q2-3183A is not recommended for use during the oxidative leaching process at the baseline sparger air flow of $2.2 \mathrm{ft}^{3} / \mathrm{min} / \mathrm{ft}^{2}$.

Further testing was performed with Q2-3183A as well as three other antifoams at the idle sparger air flux of $0.22 \mathrm{ft}^{3} / \mathrm{min} / \mathrm{ft}^{2}$ during the oxidative leaching process. As discussed in section 4.7 of this report, the performance of the antifoam Q2-3183A was satisfactory during the oxidative leaching process when the sparger air flux was controlled to $0.22 \mathrm{ft}^{3} / \mathbf{m i n} / \mathrm{ft}^{2}$. With no additional Q2-3183A added just prior to the oxidative leach, the foaminess remained under 7\%. By adding $350 \mathrm{ppm}$ Q2-3183A just prior to oxidative leaching, the foaminess remained under $2 \%$. 
By running with the sparger flux at the baseline flux of $2.2 \mathrm{ft}^{3} / \mathrm{min} / \mathrm{ft}^{2}$, the foaminess rose to $57 \%$ and $44 \%$ during oxidative leaching for the cases of no additional Q2-3183A added just prior to the oxidative leach and 350 ppm Q2-3183A added just prior to oxidative leaching. Note that these foaminess values are lowered by the addition of $350 \mathrm{ppm}$ Q2-3193A to the slurry just prior to an initial caustic leach and washing procedure that was performed on the slurry prior to the oxidative leach. This test further documents that mixing should not be performed with the sparger during the oxidative leaching process.

Additional bench scale studies were also performed to test other antifoams for the oxidative leaching process. Section 4.8 of this report investigated the use of Dow Corning Q2-3315, DeBourg 747, and Dow Corning 1520US antifoams during the oxidative leaching process. In all cases, the Q2-3183A antifoam outperformed the other antifoams tested.

Washing of the oxidative leached slurry was performed with six successive dilutions of $2.7 \mathrm{ml}$ inhibited water to $30 \mathrm{ml}$ of slurry. Between dilutions, the wash and slurry would be centrifuged, and an equivalent amount of supernate would be drawn off. The appearance of the supernate from the washes provides some clues to the oxidative leaching process. Table 4 summarizes the supernate appearance for the different runs.

Table 4. Wash Supernate Appearance After Oxidative Leach

\begin{tabular}{|l|l|}
\hline Test & Supernate Appearance \\
\hline High Cr, No Antifoam & Clear purple, then green, then yellow \\
\hline High Cr, with Antifoam & Cloudy yellow \\
\hline Low Cr, No Antifoam & Clear yellow \\
\hline Low Cr, with Antifoam & Clear yellow \\
\hline
\end{tabular}

For the high $\mathrm{Cr}$, no antifoam case, the purple color of the supernate indicates that there was still some reactive $\mathrm{NaMnO}_{4}$ left over after the leaching process. This $\mathrm{NaMnO}_{4}$ could damage the ion exchange columns downstream in the WTP process. One possible reason for the remaining $\mathrm{NaMnO}_{4}$ is mixing of the slurry only occurred for about 5 minutes per hour for the first seven hours of the leach process and then 5 more minutes at the end of the process.

For the high $\mathrm{Cr}$, with antifoam case, the cloudiness of the supernate is an indication of the antifoam degradation due to reaction with the $\mathrm{NaMnO}_{4}$. The low $\mathrm{Cr}$, with antifoam runs did not create a cloudy wash permeate. Two reasons why the high Cr runs showed antifoam degradation whereas the low $\mathrm{Cr}$ runs did not are: 1) the high $\mathrm{Cr}$ runs had a $6 \mathrm{X}$ greater concentration of $\mathrm{NaMnO}_{4}$ than the low Cr runs, 2) the high Cr runs used $2 \mathrm{X}$ and $4 \mathrm{X}$ the amount of antifoam as the low Cr runs used.

Washing of the low $\mathrm{Cr}$, with antifoam runs caused an increase in the slurry foaminess. This is probably due to the dilution and removal of the antifoam from the slurry during washing. Washing of the runs which had no antifoam caused a decrease in slurry foaminess. This is probably due to the reduction of dissolved solids. 
WSRC-TR-2005-00263, REV. 0

SRNL-RPP-2005-00039, REV. 0

The simulant for these experiments came from the SIPP operation ${ }^{5}$, campaign IV. This simulant was washed AY-102/C-106 simulant that did not have the caustic leach performed on it ${ }^{5}$.

In the process of making up a foamy simulant, two variables were found to have a major impact on the foaminess of the simulant. The first was the dissolved solids content of the permeate and the second was the undissolved solids content of the slurry. These

observations are consistent with literature ${ }^{9}$. For both variables, there was a point of maximum foaminess where any increase or decrease in solids content would cause a decrease in foaminess. The final simulant was made at the solids concentrations of maximum foaminess and had a concentration of $12.9 \mathrm{wt} \%$ undissolved solids and $~ 11 \mathrm{wt} \%$ dissolved solids. 
WSRC-TR-2005-00263, REV. 0

SRNL-RPP-2005-00039, REV. 0

\subsection{REFERENCES}

1. Hani Abodishish, Test Specification - "Evaluation Of Foaming/Antifoaming In WTP Tanks Equipped With Pulse Jet Mixers And Air Spargers.” 24590-WTP-TSP-050001, Hanford, WA. March, 2005.

2. Baich, M. A., Stone, M. E., White, T. L., Calloway, T. B., "Waste Treatment Plant Evaporation: Antifoam Performance,” WSRC-TR-2003-00216, Rev. 0, Westinghouse Savannah River Company, August 2003.

3. Hassan, N. M., Jones, T. M., Daniel, W. E. Hansen, E. K., Eibling, R. E. Calloway, T. B., "Evaluation of Foaming/Antifoaming In WTP Tanks Equipped With Pulse Jet Mixers And Air Spargers,” WSRC-TR-2004-00387, Westinghouse Savannah River Company, September 2004.

4. Burket, P. R., Crawford, C. L., White, T. L., Duffey, C. E., Calloway, T. B., “Task Technical and Quality Assurance Plan for Evaluation of Foaming/Antifoaming in the WTP Aluminum and Oxidative Leaching Processes,” WSRC-TR-2005-00127, Westinghouse Savannah River Company, March 2005.

5. Duignan, M. R., Adamson, D. J., Calloway, T. B., Fowley, M. D., Qureshi, Z. H., Steimke, J. L., Williams, M. R., Zamecnik, J. R., “Final Report: RPP-WTP SemiIntegrated Pilot Plant,” WSRC-TR-2005-00105, Westinghouse Savannah River Company, February 2005.

6. Crawford, C. L., Duffey, C. E., Burket, P. R., Calloway, T. B., “Task Technical and Quality Asurrance Plan forH2 Generation Rate Scoping Study of DOW Corning Antifoam Agent," WSRC-TR-2005-00144, Westinghouse Savannah River Company, March 2005.

7. Boh, G. L., "System Description for Ultrafiltration Process System (10-UFP)," 24590-PTF-3YD-UFP-00001, Rev. A, Bechtel, December 2001.

8. Poirier, M. R., Burket, P. R., Siler, J. L., Zamecnik, J. R., "Filtration, Washing, and Leaching of a AY-102/C-106 Sample," WSRC-TR-2003-00240 rev. 0, Westinghouse Savannah River Company, June 2003.

9. Nikolov, A. D., D. T. Wasan, D. Hunge, A. D. Edwards, Presented at $61^{\text {st }}$ Annual Technical Conference and Exhibition of Society of Petroleum Engineers, New Orleans, L. A. October 5-8, 1986; SPE Preprint 15443.

10. Titration of Oxalate with Permanganate, http://www.bgsu.edu/departments/chem/faculty/endres/ch128/oxalate.htm, Bowling Green State University. 
WSRC-TR-2005-00263, REV. 0

SRNL-RPP-2005-00039, REV. 0

\section{APPENDIX A. HIGH CHROMIUM ADDITION TO SIMULANT FOR OXIDATIVE LEACH}

\section{High Chromium in AY-102 Slurry for Oxidative Leach}

RPP requested an upper limit of $12 \mathrm{mg} \mathrm{Cr} / \mathrm{g}$ of washed solids for oxidative leaching. Though we are working with $12.9 \mathrm{wt} \%$ washed slurry, we are going to add Cr to it as if it were 20 wt $\%$ slurry.

The ADS analysis of the $12.9 \mathrm{wt} \%$ slurry reports $398 \mathrm{ug} \mathrm{Cr} / \mathrm{g}$ slurry.

We will perform two $30 \mathrm{ml}$ foam tests without antifoam and two $30 \mathrm{ml}$ foam tests with antifoam for a total of $120 \mathrm{ml}$ of slurry to be treated. An extra $40 \mathrm{ml}$ of slurry will be made up to account for losses. Therefore $160 \mathrm{ml}$ of slurry will be made up to have $12 \mathrm{mg} \mathrm{Cr} / \mathrm{g}$ slurry.

Total Slurry $=160 \mathrm{ml}$ slurry $\times \frac{1.18 \mathrm{~g} \text { slurry }}{\mathrm{ml} \text { slurry }}=188.8 \mathrm{~g}$ slurry

Cr in Slurry $=188.8 \mathrm{~g}$ slurry $\times \frac{.398 \mathrm{mg} \mathrm{Cr}}{\mathrm{g} \text { slurry }}=75 \mathrm{mg} \mathrm{Cr}$

$\mathrm{MW}$ of $\mathrm{Cr}_{2} \mathrm{O}_{3}=152 \mathrm{~g} / \mathrm{mol}$

$\mathrm{MW}$ of $\mathrm{Cr}=52 \mathrm{~g} / \mathrm{mol}$

$\frac{\mathrm{g} \mathrm{Cr}_{2} \mathrm{O}_{3}}{\mathrm{gCr}}=\frac{152 \mathrm{~g} \mathrm{Cr}_{2} \mathrm{O}_{3}}{\mathrm{~mol} \mathrm{Cr}_{2} \mathrm{O}_{3}} \times \frac{\mathrm{mol} \mathrm{Cr}_{2} \mathrm{O}_{3}}{2 \mathrm{~mol} \mathrm{Cr}} \times \frac{\mathrm{mol} \mathrm{Cr}}{52 \mathrm{~g} \mathrm{Cr}}=1.4615$

Chromium addition required:

$\frac{75 \mathrm{mgCr}+x \mathrm{mgCr}}{188.8 \mathrm{~g} \text { slurry }+\left(1.4615 \times \frac{x \mathrm{mgCr}}{1000}\right)}=\frac{12 \mathrm{mgCr}}{\mathrm{g} \text { solids }} \times \frac{.2 \mathrm{~g} \text { solids }}{\mathrm{g} \text { slurry }}$

379 mg Cr needed.

$\mathrm{Cr}_{2} \mathrm{O}_{3}$ to add $=0.379 \mathrm{~g} \mathrm{Cr} \times \frac{1.4615 \mathrm{~g} \mathrm{Cr}_{2} \mathrm{O}_{3}}{\mathrm{gCr}}=0.554 \mathrm{~g} \mathrm{Cr}_{2} \mathrm{O}_{3}$

Instruction:

Add 0.554 grams $\mathrm{Cr}_{2} \mathrm{O}_{3}$ to $188.8 \mathrm{~g}$ of slurry. 
WSRC-TR-2005-00263, REV. 0

SRNL-RPP-2005-00039, REV. 0

\section{APPENDIX B. PERMANGANATE ADDITION TO SIMULANT FOR OXIDATIVE LEACH}

\section{Sodium Permanganate Addition for High Cr Leaching}

Per WTP-RPT-117, 1M NaMnO 4 is added at a 1.1:1 ratio, based on the $\mathrm{Cr}$ in the unwashed slurry, to the washed slurry.

$\frac{30 \mathrm{ml} \text { slurry }}{\text { column }} \times \frac{1.18 \mathrm{~g}}{\mathrm{ml} \text { slurry }}=\frac{35.4 \mathrm{~g} \text { slurry }}{\text { column }}$

Cr to treat per column

$\frac{12 \mathrm{mg} \mathrm{Cr}}{\mathrm{g} \text { solids }} \times \frac{.2 \mathrm{~g} \text { solids }}{\mathrm{g} \text { slurry }} \times 35.4 \mathrm{~g}$ slurry $\times \frac{\mathrm{gCr}}{1000 \mathrm{mg} \mathrm{Cr}} \times \frac{\mathrm{mol} \mathrm{Cr}}{52 \mathrm{~g} \mathrm{Cr}}=0.00163 \mathrm{molCr}$

ml of $1 \mathrm{M} \mathrm{NaMnO}$ to add per column

$0.00163 \mathrm{~mol} \mathrm{Cr} \times \frac{1.1 \mathrm{~mol} \mathrm{MnO} 4}{\mathrm{~mol} \mathrm{Cr}} \times \frac{1000 \mathrm{ml}}{\mathrm{mol} \mathrm{NaMnO}_{4}}=1.8 \mathrm{ml}^{\mathrm{MM} \mathrm{NaMnO}} \mathrm{N}_{4}$

For the Low Cr run, $0.3 \mathrm{ml}$ of $1 \mathrm{M} \mathrm{NaMnO}_{4}$ was added. $0.48 \mathrm{ml}$ of $1 \mathrm{M} \mathrm{NaMnO}_{4}$ should have been added, but a calculational error of using $12.5 \mathrm{wt} \%$ solids versus $20 \mathrm{wt} \%$ solids skewed the amount of $\mathrm{NaMnO}_{4}$ added low. 


\section{APPENDIX C. FOAMING PICTURES}

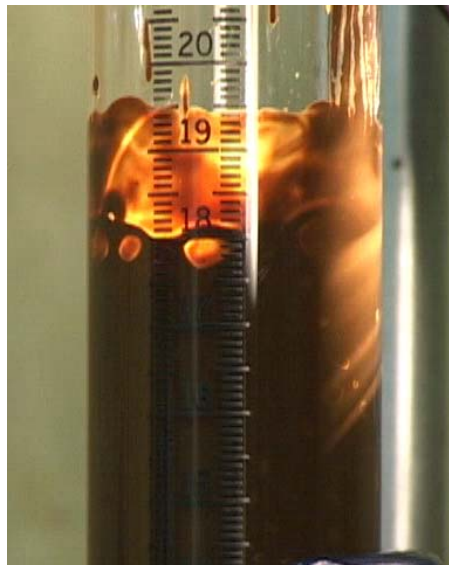

Baseline Simulant

Flux $=2.2 \mathrm{ft}^{3} / \mathrm{min} / \mathrm{ft}^{2}$

Foam ht. $=18 \mathrm{~cm}$

Foaminess $=283 \%$
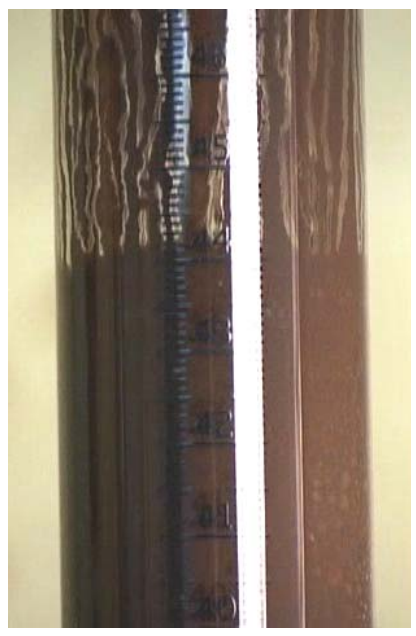

Oxidative Leach of High Cr

Simulant at 4 hours after start of reaction, Flux $=2.2 \mathrm{ft}^{3} / \mathrm{min} / \mathrm{ft}^{2}$

Foam ht. $=44 \mathrm{~cm}$

Foaminess $=1065 \%$

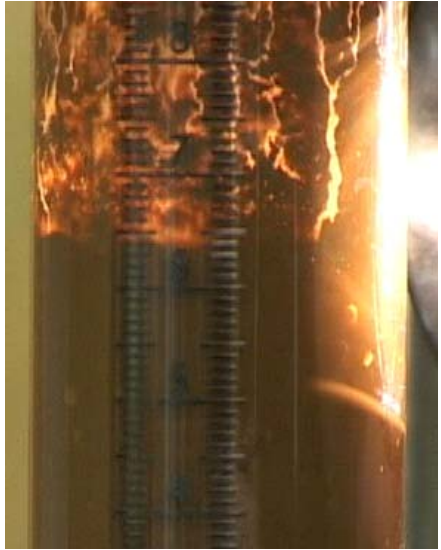

Baseline Simulant with $210 \mathrm{ppm}$ Antifoam, Flux $=2.2 \mathrm{ft}^{3} / \mathrm{min} / \mathrm{ft}^{2}$

Foam ht. $=6.5 \mathrm{~cm}$

Foaminess $=23 \%$

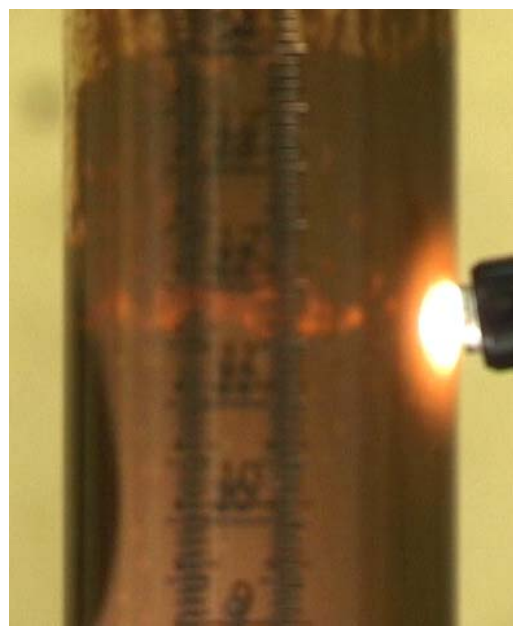

Oxidative Leach of High $\mathrm{Cr}$

Simulant with $350 \mathrm{ppm}$ Antifoam at 6 hours after start of reaction.

Flux $=2.2 \mathrm{ft}^{3} / \mathrm{min} / \mathrm{ft}^{2}$

Foam ht. $=11.5 \mathrm{~cm}$

Foaminess $=203 \%$

Antifoam Added

\section{No Antifoam}

